\title{
The Skuggliberga unit of the Oppdal area, central Scandinavian Caledonides: calc-alkaline pyroclastic volcanism in a fluvial to shallow-marine basin following a mid-Ordovician orogenic event
}

\author{
Bjørgunn H. Dalslåen', Deta Gasser ${ }^{2}$,, Tor Grenne, Morgan Ganerød² \& \\ Arild Andresen ${ }^{1}$ \\ ${ }^{1}$ Department of Geosciences, University of Oslo, PO Box 1047, Blindern, 0316 Oslo, Norway \\ ${ }^{2}$ Department of Environmental Sciences, Western Norway University of Applied Sciences, Røyrgata 6, \\ 6856 Sogndal, Norway \\ ${ }^{3}$ The Geological Survey of Norway, Leiv Eirikssons vei 39, 7040 Trondheim, Norway
}

E-mail corresponding author (b.h.dalslaen@geo.uio.no):b.h.dalslaen@geo.uio.no

Keywords:

- Scandinavian Caledonides

- Arc volcanism

- Detrital zircon

- Volcanic deposits

- Late Ordovician

Electronic supplement 1: $\mathrm{U}-\mathrm{Pb}$ detrital zircon data

Electronic supplement 2: Ar-Ar data

Received:

23. November 2020

Accepted:

24. February 20201

Published online:

5. August 2021
We present field observations, geochemical data and detrital zircon U-Pb ages from the newly defined Skuggliberga unit of the Oppdal area, central Norwegian Caledonides. The unit occurs in two separate areas, where it unconformably overlies the c. 475-470 Ma Trollhøtta and Skarvatnet units. The Skuggliberga unit consists of a local basal conglomerate and a cross-stratified to massive sandstone, overlain by bedded, fragment-bearing volcanic rocks, probably representing pyroclastic units erupted in a terrestrial or shallow-marine setting. Geochemical data from nine samples of volcanic rocks show calc-alkaline basaltic andesitic and andesitic compositions, with negative $\mathrm{Nb}-\mathrm{Ta}$ anomalies indicating a continental arc-related signature, which is distinctly different from the underlying Trollhøtta and Kinna volcanic rocks. One sandstone sample from the Skaret succession, below the unconformity, is dominated by Palaeozoic detrital zircons, with a major peak at c. $490 \mathrm{Ma}$. Two sandstone samples from the Skuggliberga unit contain Archaean, Palaeo- to Neoproterozoic and Palaeozoic detrital zircons. Different methods to calculate the maximum depositional age for these samples vary by up to $50 \mathrm{Myr}$ (from c. 427 to c. $475 \mathrm{Ma}$ ), some estimates being younger than the c. 435 Ma plutonic Innset massif that intrudes the Skuggliberga unit, indicating that the youngest detrital zircons must have experienced concealed lead loss. This lead loss could have occurred during regional metamorphism of the unit; an $\mathrm{Ar}-\mathrm{Ar}$ plateau age of $416 \pm 3 \mathrm{Ma}$ was derived for biotite in one Skuggliberga volcanic sample representing cooling after regional greenschist-facies metahism. The Skuggliberga unit has no known direct correlative in the Trondheim Nappe Complex but overlaps in age and geochemical characteristics
Dalslåen, B.H., Gasser, D., Grenne, T., Ganerød, M. \& Andresen, A. 2021: The Skuggliberga unit of the Oppdal area, central Scandinavian Caledonides: calc-alkaline pyroclastic volcanism in a fluvial to shallow-marine basin following a mid-Ordovician orogenic event. Norwegian Journal of Geology 101, 202107. https://dx.doi.org/10.17850/njg101-2-2. 
with arc-related plutonic rocks along the central Norwegian coast, indicating that it represents the surface expression of the latter. The orogenic phase predating Skuggliberga deposition is probably related to Taconian accretionary events along the Laurentian margin.

\section{Introduction}

The Scandinavian Caledonides preserve remnants of the ancient lapetus Ocean, which opened in the Late Neoproterozoic and closed during the convergence and final collision of Laurentia, Baltica and Avalonia in the Palaeozoic (e.g., Wilson, 1966; Gee et al., 2008; Corfu et al., 2014; Domeier, 2016). Remnants of this ocean can be found all along the Scandinavian Caledonides and are particularly abundant in the Trondheim and Köli nappe complexes (Fig. 1A). These lapetus-derived rock units mainly comprise Cambrian to Early Ordovician supra-subduction zone (SSZ) ophiolites and their volcanosedimentary cover successions, as well as arc-related plutonic rocks. Whereas most of the c. 500-480 Ma SSZ ophiolite fragments, including Lyngen, Leka, Løkken-Vassfjellet-Bymarka (LVB), Gullfjellet and Karmøy (Fig. 1A; e.g., Pedersen et al., 1992; Pedersen \& Dunning, 1997; Slagstad et al., 2014) have been investigated in detail, many aspects of the stratigraphy, depositional environment, tectonic setting and absolute ages of the overlying Ordovician to Silurian cover successions remain unresolved.

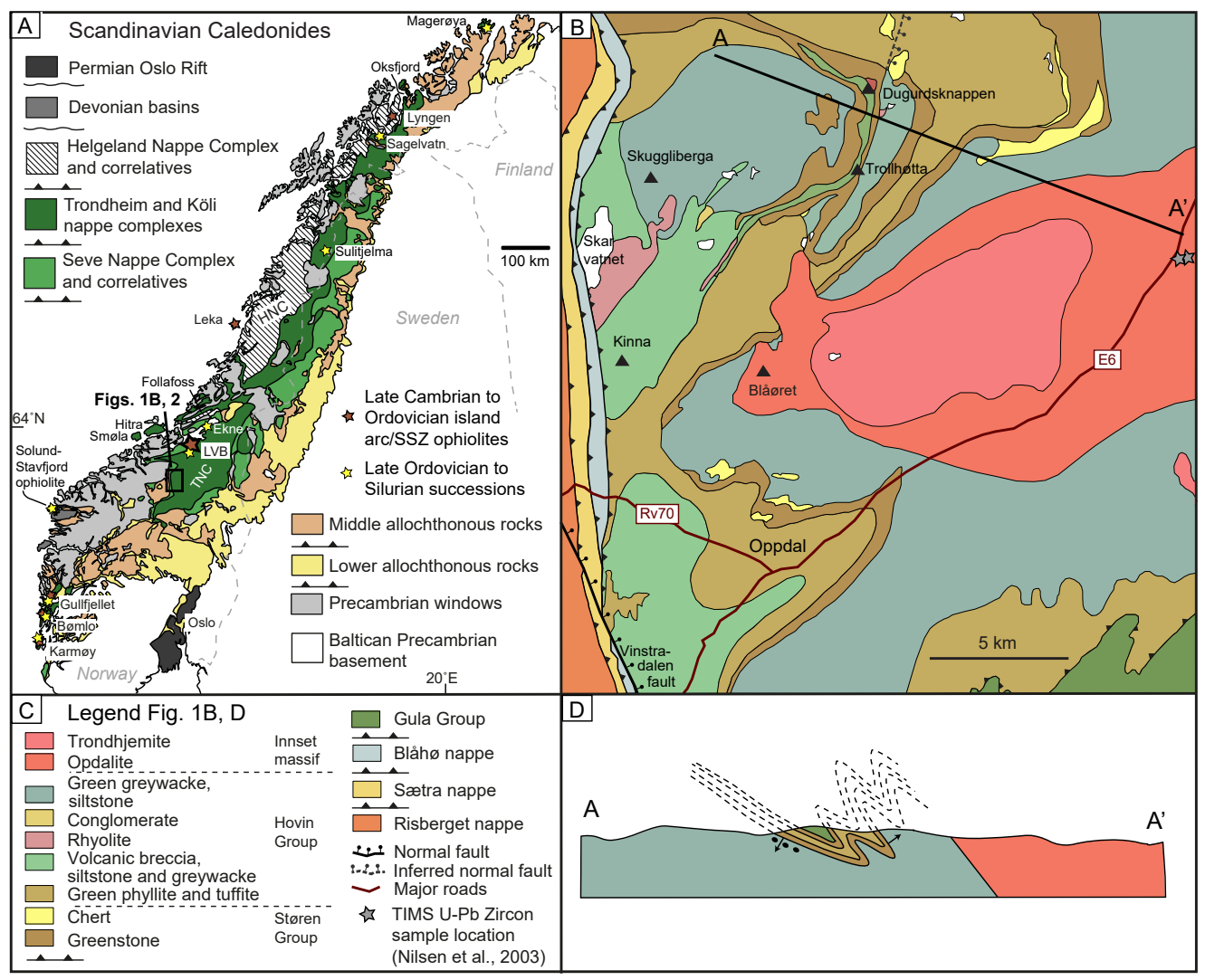

Figure 1. (A) Regional map of the Scandinavian Caledonides. Abbreviations: TNC - Trondheim Nappe Complex; LVB Løkken-Vassfjellet-Bymarka ophiolite; HNC - Helgeland Nappe Complex. (B) Geological map of the Oppdal area according to Nilsen \& Wolff (1989), showing the extent of the Støren and Hovin groups. (C) Legend to Fig. 1B; applies also to Fig. 1D. (D)Interpretative cross-section of the Oppdal area by Rohr-Torp (1972) (slightly modified). Parts of the Trollhøtta succession were correlated with the Gula Group (dark green) and interpreted to lie in the core of a synformal anticline in the overturned and folded succession, whereas the Skuggliberga unit was not recognised as a separate unit but interpreted to be part of the overturned Hovin succession. See Fig. 2B for comparison. 
The Trondheim Nappe Complex (TNC) is one of the larger areas within the Scandinavian Caledonides where lapetus-derived SSZ ophiolites, marginal basins and their cover successions are preserved (Fig. 1A). The Oppdal area within the southern TNC has recently received considerable attention due to the discovery of a peculiar volcano-sedimentary succession consisting of highly enriched, largely pyroclastic, mafic to felsic volcanic rocks and MORB-like pillow basalts intercalated with turbiditic sedimentary rocks, indicating a hitherto little-known spreading environment within a marginal basin of lapetus at c. 475-470 Ma (Stokke et al., 2018; Dalslåen et al., 2020a; Dalslåen et al., 2020b). This succession was shown by Stokke et al. (2018) to have been deformed and eroded prior to the deposition of cross-stratified sandstones and andesitic volcanic rocks, highlighting the existence of a major angular unconformity in the area. Based on five overlapping near-concordant detrital zircon grains within one sandstone sample, Stokke et al. (2018) concluded with a post-427 Ma age for the sandstones and andesitic rocks, postulating a hitherto unknown Late-Silurian or younger volcanosedimentary phase within the area.

In this contribution, we review the geology of the TNC in the Oppdal area, and add new field observations, geochemical data, $\mathrm{U}-\mathrm{Pb}$ detrital zircon and $\mathrm{Ar}-\mathrm{Ar}$ data from the sandstones and volcanic rocks above the regional unconformity. We compare our results with the earlier map compilation of Nilsen \& Wolff (1989) and the interpretations of Stokke et al. (2018), and discuss our findings within the framework of other lapetus-related cover successions within the Scandinavian Caledonides.

\section{Geology of the TNC in the Oppdal area}

The geology of the Oppdal area is well known for the occurrence of quartzite schist ('Oppdalsskifer') mined in numerous quarries south of the Oppdal town centre, within the Sætra nappe. The tectonostratigraphically lower nappes in the Oppdal region (Åmotsdal, Risberget, Sætra and Blåhø; Fig. 1B, C) are amphibolite to granulite facies (e.g., Krill, 1985). The lower-grade metamorphic rocks of the overlying Trondheim Nappe Complex are less well known, and have been loosely referred to as the Tronget unit (e.g., Krill, 1980; Gee et al., 1985). Holmsen (1955) described a variety of sedimentary and volcanic rocks from this area, which Nilsen \& Wolff (1989) on their regional geological map assigned to the following two main groups: (1) metabasalts and green layered tuffite and phyllite with minor rhyolite, volcanic breccia, siltstone and greywacke of the Støren Group, and (2) green greywacke and shale as well as grey siltstone and shale of the younger Hovin Group (Fig. 1B, C). Farther north in the Trondheim area, where the Støren and Hovin groups were originally defined, the two are separated by an unconformity which marks a tectonic event traditionally referred to as "the Trondheim disturbance" (e.g., Vogt, 1945). The contact between the Støren and Hovin groups is not easily recognised as an unconformity on the map of Nilsen \& Wolff (1989; Fig. 1B), but Rohr-Torp (1972) described several deposits of polymictic conglomerates which he interpreted as being positioned at the base of the Hovin Group (Fig. 1D). Moreover, Rohr-Torp (1972) interpreted grey siltstones and shales running through the Trollhøtta mountain (Fig. 1B, C) as western correlatives of the Gula Group, which has its principal location farther east in the TNC. Based on this correlation, Rohr-Torp (1972) postulated a general inversion of the tectonostratigraphy, with the presumably oldest Gula Group being located structurally above the younger Støren and Hovin groups (Fig. 1D). The supracrustal rocks of the Oppdal area were intruded by a major pluton (Fig. 1B, C) termed the Innset massif (Goldschmidt, 1916; Rohr-Torp, 1974), which ranges from norite through orthopyroxene-bearing granodiorite ('opdalite') to trondhjemite (Fig. 1B; Nilsen et al., 2003). Zircons from a biotite norite and a trondhjemite from this body have been dated by U-Pb TIMS at $435.8 \pm 0.9 \mathrm{Ma}$ and $434.8 \pm 0.5 \mathrm{Ma}$, respectively (Nilsen et al., 2003; Fig. 1B). 
Stokke et al. (2018) demonstrated the existence of metabasaltic rocks with a clear MORB-type geochemical composition within the Støren Group rocks at Dugurdsknappen (Fig. 2A). This geochemical composition is different from that of the SSZ-type LVB ophiolites with which the Støren Group traditionally has been correlated. These MORB-type metabasalts, together with intercalated turbiditic silt- and sandstones and minor rhyolites dated at $473 \pm 1$ and $472 \pm 1 \mathrm{Ma}$, were referred to as the Trollhøtta unit by Dalslåen et al. (2020b; Fig. 2A). Locally interfingering with Trollhøtta metabasalts is

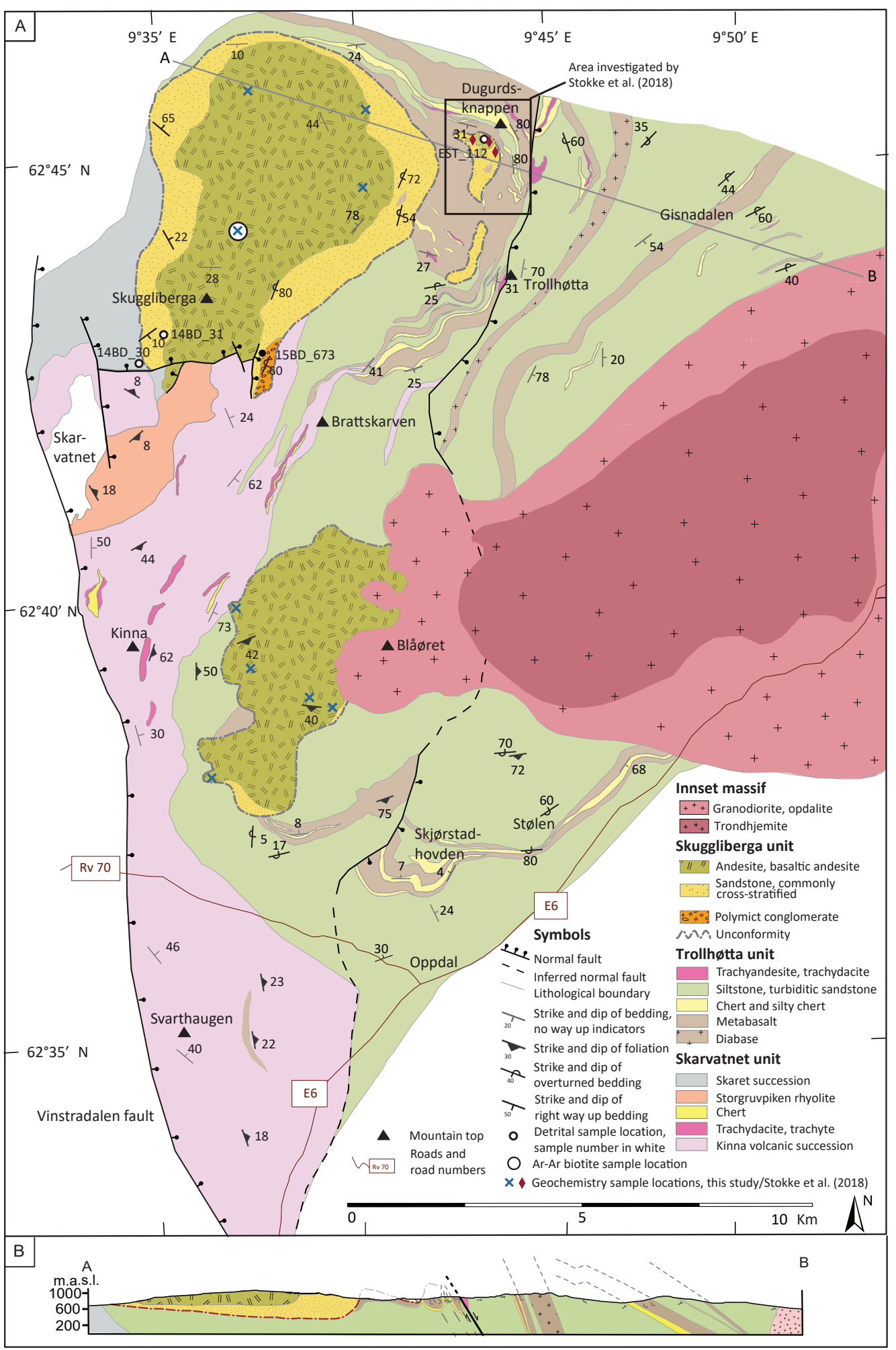

Figure 2. (A) Geological map of the Oppdal area according to our own mapping. (B) Interpretative profile through the northern part of the Skuggliberga and Trollhøtta units, modified from Stokke et al. (2018) and Dalslåen et al. (2020b). 
the Kinna metavolcanic succession (Fig. 2A), which consists of $474 \pm 1$ Ma mafic to felsic pyroclastic deposits strongly enriched in highly incompatible elements, and which is overlain by the slightly younger (470 $\pm 1 \mathrm{Ma}$ ) Storgruvpiken metarhyolite (Dalslåen et al., 2020a, b). The Kinna and Storgruvpiken metavolcanic rocks, together with associated metasedimentary rocks of the Skaret succession, are informally assigned to the Skarvatnet unit (Fig. 2; Dalslåen et al., 2020a). The above ages indicate that the volcanosedimentary Trollh $\varnothing t t a$ unit and the Kinna and Storgruvpiken metavolcanic rocks are c. 10 Myr younger than the LVB ophiolites to the north (c. 487-480 Ma, e.g. Slagstad et al., 2014).

The mapping by Dalslåen et al. (2020b) showed that large parts of what was previously assigned to the Hovin Group, particularly in the Gisnadalen and Skjørstadhovden-Stølen areas (Fig. 2A), are turbiditic rocks intercalated with Trollh $\emptyset$ tta metavolcanic rocks. Hence, they are integral parts of the Lower Ordovician succession and not unconformably overlying it (compare Fig. 1B with Fig. 2A). Dalslåen et al. (2020b) also presented a different interpretation of the Rohr-Torp profile (compare Fig. 1D with Fig. 2B), with no Gula-type sedimentary rocks in the studied area and with general younging of the Trollhøtta succession towards the west. This implies that the beds are partly overturned, but not totally inverted as Rohr-Torp (1972) suggested. The contact between the St $\varnothing$ ren and Hovin groups shown in the western part of Rohr-Torp's profile as being inverted and with a basal conglomerate, was identified by Stokke et al. (2018) as representing a major angular unconformity on previously folded Trollhøtta rocks, overlain by right-way-up, less deformed and cross-stratified sandstones and metavolcanic rocks. Based on near-concordant detrital zircon data, Stokke et al. (2018) interpreted these rocks to have been deposited after c. $427 \mathrm{Ma}$, which is considerably younger than the fossil-bearing Mid- to Upper Ordovician Hovin Group of the Trondheim area.

The geological map in Fig. 2A delineates the angular unconformity identified by Stokke et al. (2018) over a larger area. On this map, the rocks above the unconformity were informally termed the Skuggliberga unit by Dalslåen et al. (2020a, b), named after the main mountain northeast of lake Skarvatnet. The main aim of the current contribution is to describe the field relations, geochemical composition and age of this Skuggliberga unit in more detail.

\section{Field observations}

Our detailed mapping in the Oppdal area revealed the presence of the angular unconformity identified by Stokke et al. (2018) over a larger area, and overlying rocks were identified in two geographically separate areas $\mathrm{N}-\mathrm{NW}$ of Oppdal (Fig. 2A). The northern area is the largest, covering approximately $32 \mathrm{~km}^{2}$, of which $20.5 \mathrm{~km}^{2}$ are volcanic rocks and $11.5 \mathrm{~km}^{2}$ are sedimentary rocks. The southern area covers approximately $13 \mathrm{~km}^{2}$ and consists mainly of volcanic rocks. The areas identified by Stokke et al. (2018) are smaller deposits east of the main northern area (Fig. 2A). All rocks have undergone greenschist-facies regional metamorphism, but the prefix 'meta' is omitted in the following descriptions and discussions for simplicity.

\section{Northern area}

The northern area is preserved within an asymmetric open syncline (Fig. 2A, B). In the southern part of this area, a polymictic conglomerate of c. $100 \mathrm{~m}$ thickness is found at the base of the succession (Fig. 2A). The 5-30 cm conglomerate clasts are generally well rounded and consist mainly of quartzite, aplitic granite, pink felsic volcanic rocks, fine-grained marble, Kinna-type vesicular volcanic rocks with abundant phenocrysts, greenstone, jasper and chert (Fig. 3A, B). The matrix consists mainly of quartz 


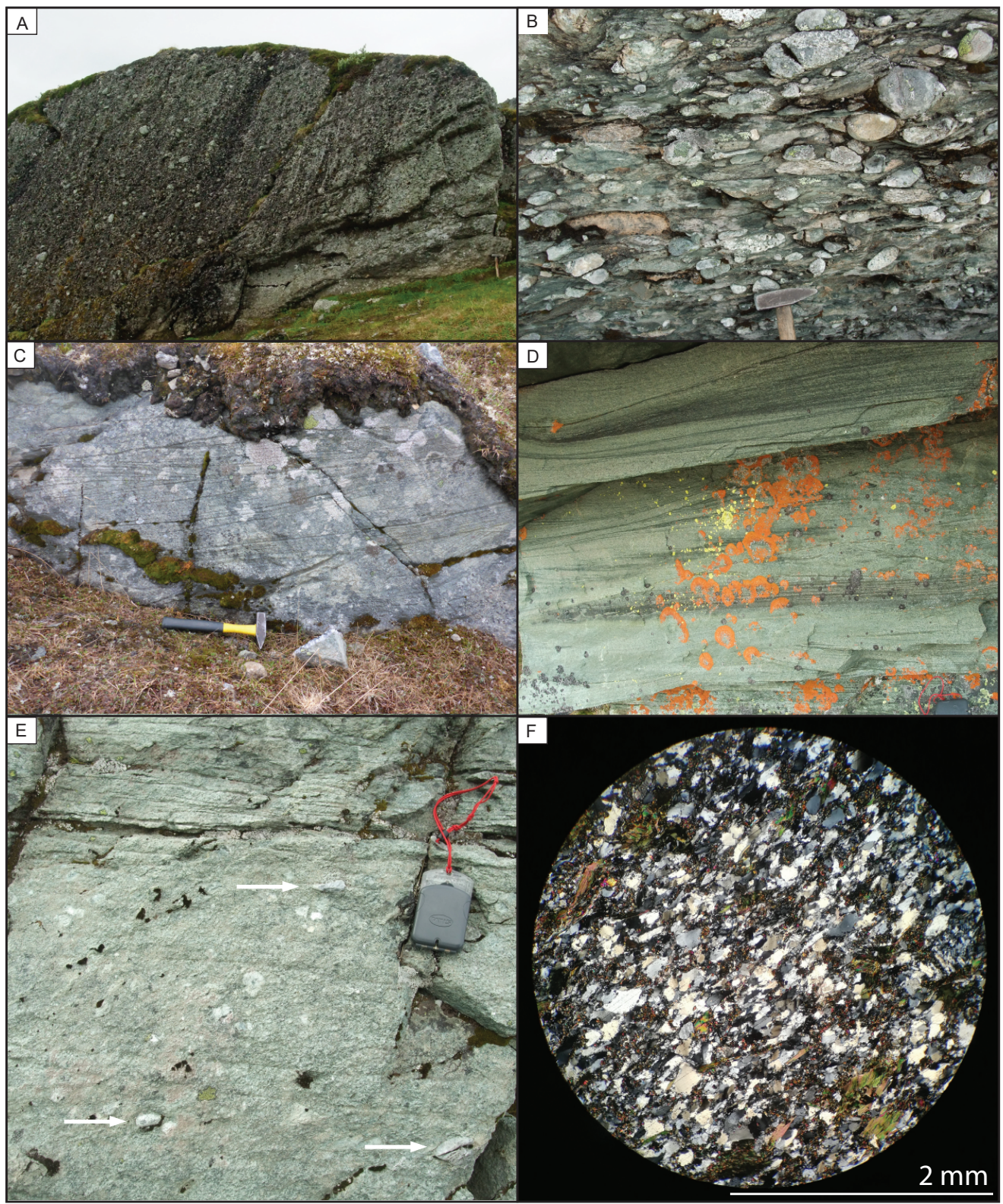

Figure 3. Field photos of the sedimentary rocks of the Skuggliberga unit, northern area. (A) Massive conglomerate, with a penetrative foliation dipping gently to the east (to the left in the picture, which is taken towards south). This foliation corresponds to foliation D3 of Stokke et al. (2018). Hammer for scale in the lower-right corner [UTM (32) 532313.6953857]. (B) Polymictic, foliated conglomerate; picture taken towards east [UTM (32) 532017.6953193]. (C) Cross-stratified sandstone [UTM(32) 529546.6954814]. (D) Cross-stratified bedded greenish sandstone, compass for scale in the lower-right corner [UTM (32) 529638.6953950]. (E) Massive sandstone with arrows pointing to scattered quartzite clasts, with thinly bedded sandstone on top [UTM (32) 532366.6954778]. (F) Photomicrograph of sample 14BD_31, the cross-stratified sandstone in Fig. 3E. Crossed polarizers.

and mica. The clasts are generally flattened and the matrix exhibits a penetrative foliation corresponding to the regional, generally ESE-dipping, tectonic foliation. The conglomerate generally fines upwards, with interbedded sandstone in its upper parts.

Except for the southernmost part, where the contact to the Skarvatnet unit is faulted, an up to c. $100 \mathrm{~m}$-thick sandstone unit occurs around the entire northern area, conformably overlying the conglomerate or resting directly on the angular unconformity to the Trollhøtta and Skarvatnet units (Fig. 2A). The immature to submature sandstone is typically greenish, fine- to medium-grained and 
poorly sorted. Trough cross-stratified (Fig. 3C, D) and planar-laminated beds are common in the lower part; the cross-stratifications are commonly found in the southern part of the area. Up section, the bedding becomes planar, or massive and structureless, locally with scattered quartzite clasts (Fig. 3E). The sandstone is dominated by recrystallised quartz, feldspar, metamorphic biotite, chlorite and calcite (Fig. 3F), with biotite and chlorite marking the dark bedding surfaces (Fig. 3D).

The sandstone is overlain by a light-green, fine- to medium-grained, fragment-bearing volcanic rock (Figs. 2A \& 4A-D). The exposed thickness of the volcanic rock is up to $400 \mathrm{~m}$, and it is apparently

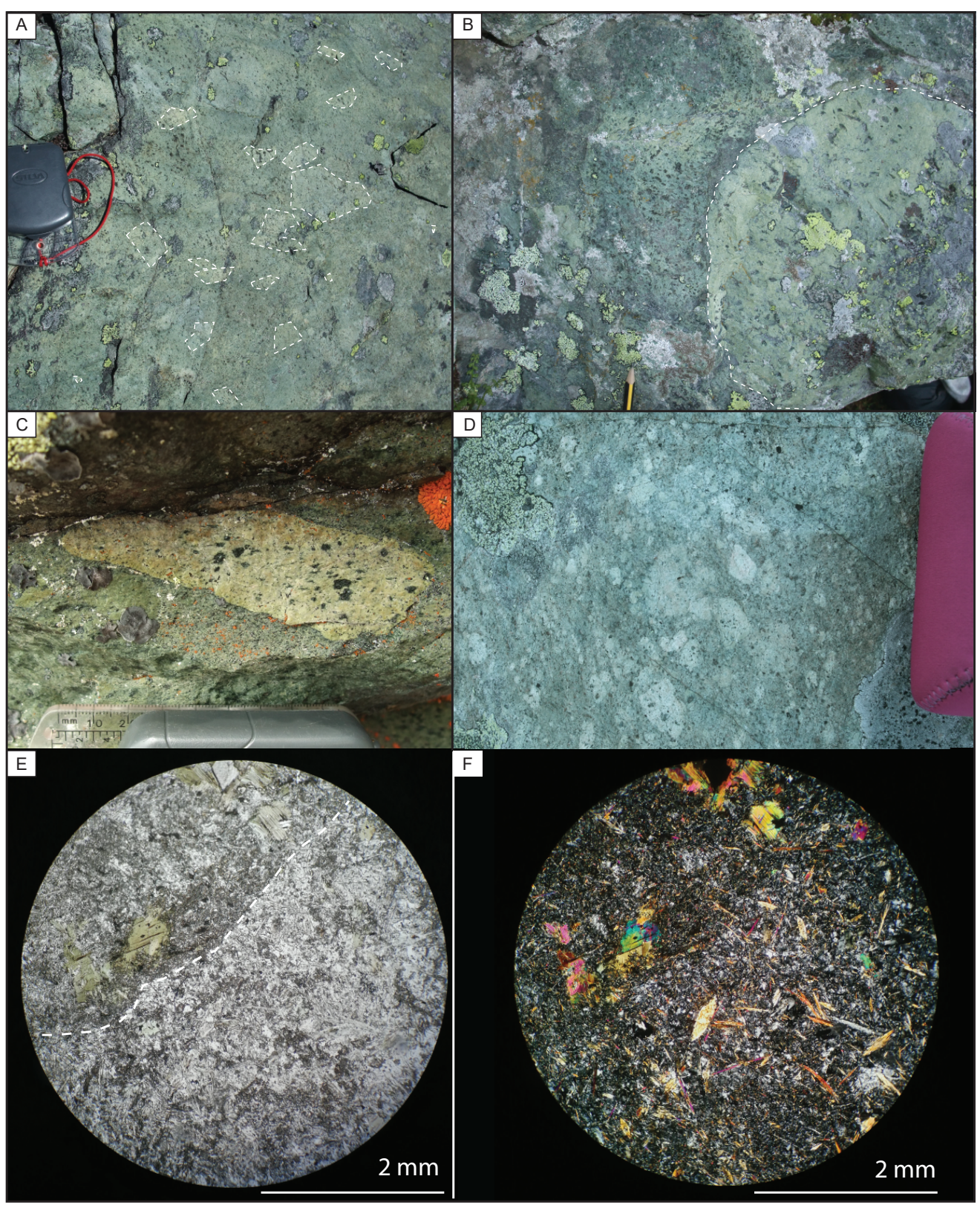

Figure 4. Field photos of the volcanic rocks of the Skuggliberga unit from the northern area. (A) Typical outcrop, where the fragments have a colour very similar to that of the matrix [UTM (32) 531625.6957167]. (B) Pale-green fragment in a similar matrix. The fragment is slightly lighter than the matrix and has larger biotite aggregates [UTM (32) 530258.6954294]. (C) Fine-grained fragment with dark hornblende/biotite aggregates, lighter coloured than the matrix [UTM (32) 530017.6955137]. (D) Small fragments in a matrix with similar colour and grain size. The pink camera case is approximately $12 \mathrm{~cm}$ [UTM (32) 532635.6955734]. (E) Photomicrograph of sample 15BD_152, the sample selected for Ar-Ar biotite dating. The upper left (above the stippled line) is a part of a fragment with large biotite grains, while the lower-right part is from the matrix. Plane-polarised light [UTM (32)531987.6956753]. (F) Same view as $4 E$, with crossed polarizers. 
thickest in the northernmost part of the area. The fragments, ranging in size from a few millimetres to $70 \mathrm{~cm}$, are angular to subangular and scattered or concentrated in faint beds. A few small $(0.5-2 \mathrm{~cm})$ fragments of pink volcanic rocks have been observed. The largest fragments are found in the northern part of the area. Other primary features are poorly preserved, but some green, sandy beds occur locally within the volcanic rock. The light-green colour of the volcanic rock is due to a high content of chlorite, epidote and zoisite. Both fragments and the matrix contain characteristic aggregates of biotite that can be up to $1 \mathrm{~cm}$ in diameter; individual grains are commonly subhedral or anhedral but euhedral biotite has also been observed. Biotite is commonly partly or totally chloritised. Heavily saussuritised plagioclase is common as phenocrysts and was apparently also a major constituent of the groundmass. Some euhedral phenocrysts of amphibole partly replaced by biotite have been observed; in thin-sections amphibole occurs as small, euhedral or partly altered pale-yellow or green grains. The overall mineralogy is similar in the matrix and the fragments, but the fragments are commonly lighter green and finer-grained, and generally have larger biotite grains/aggregates compared to the matrix (Fig. 4C, E, F).

\section{Southern area}

In the southern area, the contact to the underlying units is generally poorly exposed and the angular unconformity is less prominent, as the Trollhøtta unit is relatively flat-lying in this area. Massive, structureless, greenish sandstone is preserved in the southernmost part of the area, and a 3-5 m-thick bed of cross-stratified sandstone with scattered conglomerate clasts was observed in the eastern part close to the Innset intrusion (Fig. 2A). The cross-stratified sandstone contains up to $10 \mathrm{~cm}$ large erratic clasts of light-greenish, fine-grained volcanic rock with characteristic biotite aggregates (Fig. 5A), resembling the main Skuggliberga volcanic rock. The conglomerate beds are monomictic, consisting of the same light-greenish volcanic rocks, varying only in grain size and aggregate content (Fig. 5B). The main part of the southern area consists of a light-greenish volcanic rock similar to that of the

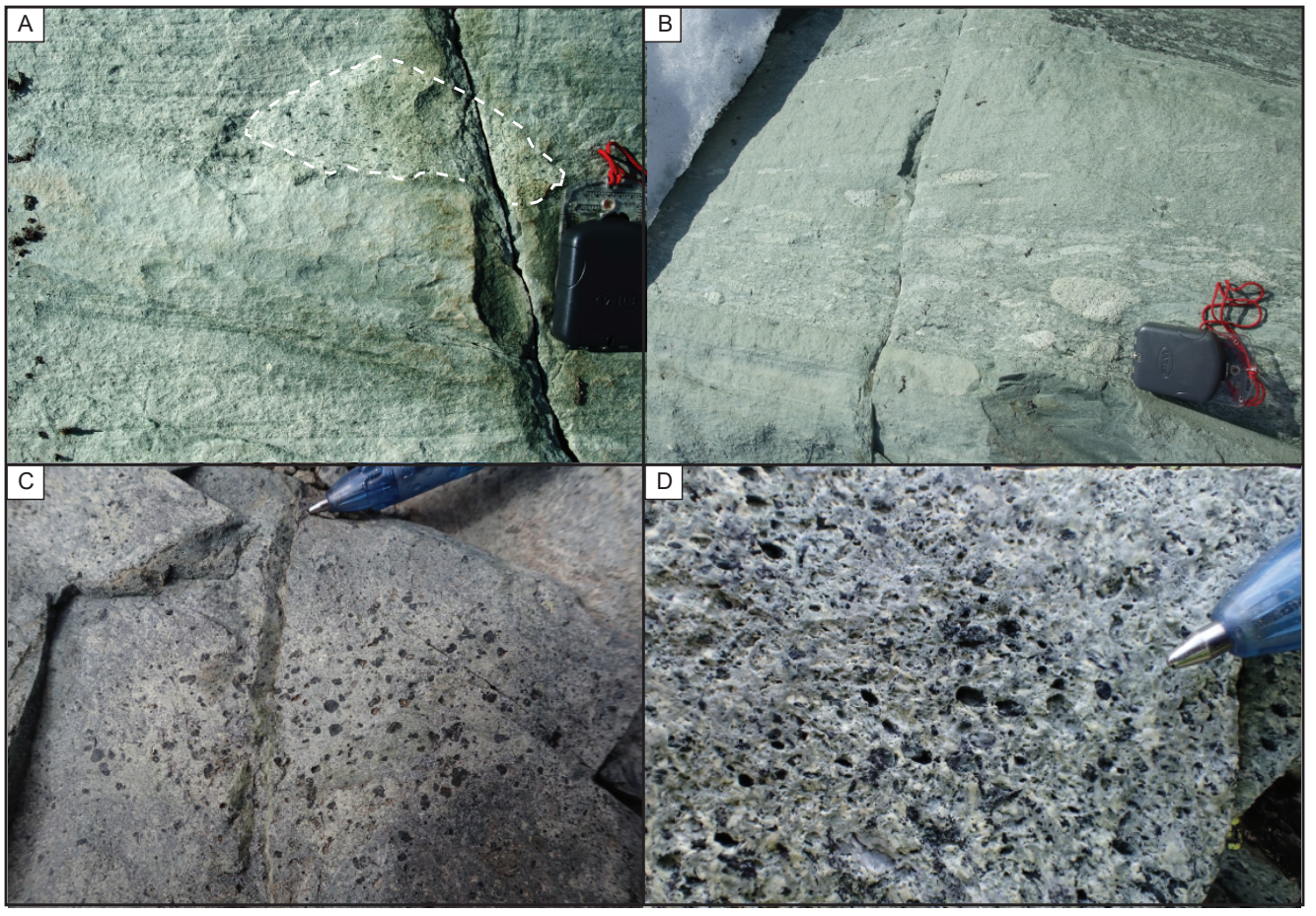

Figure 5. Field photos of sedimentary and volcanic rocks from the southern area. (A) Greenish sandstone, with a fragment of volcanic rock with characteristic aggregates of biotite outlined by the white stippled line [UTM(32) 533705.6946384]. (B) Conglomeratic bed intercalated with the sandstone in Fig. 5A, with volcanic clasts only [UTM(32) 533705.6946384]. (C) Volcanic fragment with well-preserved phenocrysts of amphibole [UTM(32)534846.6949344]. (D) Volcanic rock with phenocrysts and filled vesicles [UTM(32)534375.6948183]. 
northern area, but generally with fewer and smaller fragments. Small euhedral phenocrysts of feldspar are common, as well as dark aggregates of biotite and amphibole (Fig. 5C). Locally, up to $3 \mathrm{~mm}$-sized, roundish, calcite-filled vesicles were observed in the clasts (Fig. 5D). Greenish, sandy beds are locally interlayered with the volcanic rocks; these are coarser-grained than the volcanic rocks but have similar colour and mineralogy. In the area north and west of the Blåøret mountain (Fig. 2A), granodiorite of the Innset massif is in direct contact with the volcanic rocks. The volcanic rocks close to the contact are contact-metamorphosed and irregularly veined by granodiorite, clearly demonstrating that the Innset pluton intruded the volcanic rocks.

\section{Geochemistry}

\section{Methods}

We analysed nine samples from the Skuggliberga volcanic rocks for major and trace elements; four samples are from the northern Skuggliberga area and five samples are from the southern area (Fig. 2A). Eight samples are from matrix or homogeneous zones without visible fragments, while one sample is from a fragment. Small fragments hardly distinguishable from the matrix due to similar colour and texture are common throughout the unit, and the matrix samples are therefore likely to contain such fragments. Three samples of Skuggliberga volcanic rocks analysed by Stokke et al., (2018) are included for comparison.

All samples were analysed at the Geological Survey of Norway, Trondheim. Major elements were analysed by X-ray fluorescence (XRF) spectrometry on glass beads fused with lithium tetraborate, and trace elements were analysed by XRF spectrometry on pressed powder beads. Rare Earth Elements (REE) and selected trace elements were analysed by Laser Ablation Inductively Coupled Plasma Mass Spectrometry (LA-ICP-MS) on the glass beads used for XRF major element analysis. Common international standards were used for all methods. The results are reported in Table 1 and in Figs. 6 \& 7

Table 1. Major and trace element analyses. Elements in italics are analysed by LA-ICP-MS, other elements are analysed by XRF. LOI - LOSS on ignition.

\begin{tabular}{|c|c|c|c|c|c|c|c|c|c|}
\hline Sample & BD14.35 & BD14.36 & BD15_621 & BD15_1560 & 15BD_152 & 15BD_1490 & BD15_1209 & 15BD_1411 & 15BD_1236 \\
\hline UTM & 532558 & 532909 & 531699 & 534050 & 531987 & 531653 & 534380 & 533699 & 533107 \\
\hline (32) & 6959408 & 6959050 & 6953870 & 6957520 & 6956753 & 6948549 & 6959243 & 6946415 & 6946688 \\
\hline $\mathrm{SiO}_{2} \%$ & 54.5 & 51.5 & 49.2 & 54.6 & 54.0 & 50.5 & 55.8 & 49.9 & 58.3 \\
\hline $\mathrm{Al}_{2} \mathrm{O}_{3}$ & 16.0 & 17.2 & 15.5 & 15.3 & 15.5 & 12.9 & 15.1 & 16.1 & 17.8 \\
\hline $\mathrm{Fe}_{2} \mathrm{O}_{3}$ & 7.03 & 7.34 & 8.65 & 7.14 & 7.48 & 7.79 & 6.36 & 8.01 & 6.07 \\
\hline $\mathrm{TiO}_{2}$ & 0.74 & 1.36 & 1.16 & 0.60 & 0.87 & 0.75 & 0.573 & 0.999 & 0.73 \\
\hline MgO & 6.16 & 5.27 & 8.77 & 6.61 & 6.60 & 12.3 & 3.04 & 8.28 & 2.33 \\
\hline $\mathrm{CaO}$ & 5.92 & 8.15 & 8.16 & 8.39 & 7.81 & 7.63 & 12.2 & 7.13 & 5.81 \\
\hline $\mathrm{Na}_{2} \mathrm{O}$ & 3.43 & 3.18 & 3.30 & 2.38 & 3.48 & 2.01 & 2.97 & 3.63 & 3.05 \\
\hline $\mathrm{K}_{2} \mathrm{O}$ & 2.16 & 0.766 & 0.674 & 0.757 & 0.677 & 1.29 & 0.436 & 1.10 & 1.85 \\
\hline MnO & 0.111 & 0.103 & 0.133 & 0.122 & 0.132 & 0.122 & 0.133 & 0.120 & 0.125 \\
\hline $\mathrm{P}_{2} \mathrm{O}_{5}$ & 0.167 & 0.295 & 0.189 & 0.130 & 0.142 & 0.145 & 0.092 & 0.163 & 0.306 \\
\hline LOI & 3.01 & 2.97 & 3.33 & 2.69 & 2.37 & 3.52 & 2.68 & 2.99 & 2.44 \\
\hline
\end{tabular}




\begin{tabular}{|c|c|c|c|c|c|c|c|c|c|}
\hline $\mathrm{Ba}(p p m)$ & 409 & 148 & 179 & 299 & 166 & 508 & 126 & 211 & 898 \\
\hline Co & 30.3 & 29.6 & 39.5 & 24.4 & 29.6 & 43.5 & 16.2 & 37.8 & 8.3 \\
\hline $\mathrm{Cr}$ & 273 & 334 & 471 & 278 & 202 & 799 & 79.0 & 442 & 22.0 \\
\hline $\mathrm{Cu}$ & 44.5 & 19.6 & 20.9 & 15.7 & 20.6 & $<5$ & 1120 & 18.4 & $<5$ \\
\hline Ga & 16.4 & 19.6 & 13.9 & 15.5 & 13.5 & 12.4 & 18.0 & 14.8 & 17.6 \\
\hline $\mathrm{Ni}$ & 88.5 & 157 & 154 & 65.2 & 64.2 & 293 & 20.9 & 98.4 & $<5$ \\
\hline $\mathrm{Pb}$ & 7.9 & 20.4 & 6.5 & 12.1 & 7.8 & 11.7 & 12.1 & 8.4 & 11.9 \\
\hline $\mathbf{R b}$ & 60.1 & 20.2 & 14.9 & 17.7 & 16.9 & 35.7 & 10.4 & 40.1 & 59.8 \\
\hline Sc & 20.3 & 14.6 & 20.9 & 19.5 & 15.0 & 19.9 & 21.9 & 20.4 & 5.9 \\
\hline Sn & $<5$ & $<5$ & $<5$ & $<5$ & $<5$ & $<5$ & $<5$ & $<5$ & $<5$ \\
\hline $\mathrm{Sr}$ & 352 & 429 & 530 & 369 & 326 & 493 & 410 & 465 & 1090 \\
\hline v & 154 & 185 & 158 & 141 & 156 & 151 & 193 & 177 & 98.8 \\
\hline$Y$ & 16.6 & 26.8 & 20.2 & 13.9 & 18.8 & 15.3 & 11.6 & 21.2 & 20.8 \\
\hline Zn & 59.5 & 65.6 & 63.1 & 62.8 & 66.3 & 61.7 & 30.9 & 54.0 & 76.8 \\
\hline$Z r$ & 113 & 231 & 135 & 94.2 & 110 & 104 & 63.3 & 121 & 175 \\
\hline $\mathrm{Nb}$ & 7.15 & 13.5 & 4.13 & 6.26 & 4.63 & 5.3 & 4.2 & 3.68 & 11 \\
\hline Cs & $<10$ & $<10$ & $<10$ & $<10$ & $<10$ & $<10$ & $<10$ & $<10$ & $<10$ \\
\hline Ge & N. A. & N.A. & $<2$ & $<2$ & $<2$ & $<2$ & $<2$ & $<2$ & 2.0 \\
\hline$B e$ & 1.40 & 1.40 & 1.20 & 1.10 & $<1$ & 1.1 & $<1$ & 1.2 & 1.90 \\
\hline$L a$ & 24.9 & 37.6 & 14.0 & 18.9 & 11.5 & 23.0 & 9.75 & 14.9 & 51.4 \\
\hline $\mathrm{Ce}$ & 46.3 & 67.8 & 31.4 & 33.7 & 27.0 & 41.6 & 18.1 & 31.4 & 98.5 \\
\hline$P r$ & 5.19 & 8.20 & 4.14 & 4.11 & 3.38 & 5.15 & 2.41 & 3.95 & 11.5 \\
\hline$N d$ & 22.1 & 37 & 18.5 & 17.0 & 13.8 & 21.5 & 10.6 & 16.3 & 43.8 \\
\hline$S m$ & 4.79 & 8.32 & 4.44 & 3.87 & 3.36 & 4.74 & 2.71 & 4.16 & 7.97 \\
\hline$E u$ & 1.58 & 2.02 & 1.61 & 1.16 & 0.992 & 1.44 & 0.870 & 1.36 & 2.16 \\
\hline$G d$ & 4.27 & 7.37 & 4.21 & 3.42 & 2.74 & 3.90 & 2.39 & 3.86 & 5.37 \\
\hline$T b$ & 0.743 & 1.24 & 0.740 & 0.559 & 0.483 & 0.665 & 0.444 & 0.644 & 0.815 \\
\hline Dy & 4.52 & 7.48 & 4.48 & 3.28 & 2.93 & 3.77 & 2.72 & 4.05 & 4.66 \\
\hline Ho & 0.956 & 1.61 & 0.973 & 0.709 & 0.636 & 0.786 & 0.565 & 0.853 & 0.927 \\
\hline$E r$ & 2.55 & 4.29 & 2.37 & 1.85 & 1.65 & 2.08 & 1.52 & 2.29 & 2.41 \\
\hline $\mathrm{Tm}$ & 0.376 & 0.608 & 0.345 & 0.274 & 0.249 & 0.329 & 0.239 & 0.334 & 0.379 \\
\hline$Y b$ & 2.22 & 4.00 & 2.11 & 1.65 & 1.59 & 1.97 & 1.45 & 2.11 & 2.35 \\
\hline Lu & 0.319 & 0.581 & 0.318 & 0.252 & 0.230 & 0.315 & 0.213 & 0.316 & 0.329 \\
\hline$H f$ & 3.89 & 7.81 & 3.33 & 2.99 & 2.44 & 3.18 & 1.85 & 3.12 & 4.79 \\
\hline$T a$ & 0.523 & 0.993 & 0.273 & 0.425 & 0.334 & 0.328 & 0.299 & 0.245 & 0.714 \\
\hline$w$ & N. A. & N.A. & 0.55 & 0.26 & 0.24 & 0.41 & $<0.2$ & 0.80 & 1.58 \\
\hline$B i$ & $<0.5$ & $<0.5$ & $<0.5$ & $<0.5$ & $<0.5$ & $<0.5$ & $<0.5$ & $<0.5$ & $<0.5$ \\
\hline Th & 6.69 & 11.5 & 2.49 & 4.65 & 2.94 & 4.56 & 2.18 & 3.15 & 11.6 \\
\hline$U$ & 2.29 & 3.86 & 0.837 & 1.58 & 1.44 & 0.746 & 0.825 & 1.12 & 2.98 \\
\hline$L a_{N} / L u_{N}$ & 5.85 & 4.85 & 3.30 & 5.62 & 3.75 & 5.47 & 3.43 & 3.53 & 11.71 \\
\hline
\end{tabular}




\section{Results}

All samples fall along a calc-alkaline trend in the AFM diagram (Fig. 6A). They plot as basaltic andesite or andesite in the TAS diagram (Fig. 6B), which is confirmed by the $\mathrm{Nb} / \mathrm{Y}$ vs. $\mathrm{Zr} / \mathrm{Ti}$ diagram (Fig. 6C, Pearce, 1996) that relies on immobile elements only. In tectonic discrimination diagrams based on immobile trace elements, such as the $\mathrm{Th} / \mathrm{Yb}$ vs. Nb/Yb plot (Fig. 6D, Pearce, 2008), all samples plot within the continental arc field (Fig. 6D). In MORB-normalised multi-element plots (Fig. 7A), the samples show a marked enrichment in highly incompatible trace elements (e.g., Th $\approx 8.7-46 \times \mathrm{N}-\mathrm{MORB}$ ), with a negative anomaly at $\mathrm{Nb}-\mathrm{Ta}$ and a peak at $\mathrm{Pb}$ (12.7-40 $\times \mathrm{N}$-MORB). Except for small negative anomalies in $\mathrm{Zr}$, Ti and $\mathrm{Y}$, the pattern is flat for the less incompatible elements. Chondrite-normalised REE patterns (Fig. 7B) have relatively steep slopes for the light to middle REE and more gentle slopes for the middle to heavy $\mathrm{REE}$, with $\mathrm{La}_{\mathrm{N}} / \mathrm{Lu}_{\mathrm{N}}$ ratios ranging from 3.30 to 5.85 (except one sample with a ratio of 11.71), and no significant Eu anomalies. There is no systematic difference between samples from the southern and northern deposits. The highly enriched mafic to intermediate volcanic rocks of the Kinna volcanic succession ( Dalslåen et al., 2020a) and the MORB-like basalts from the Trollhøtta unit (Dalslåen et al., 2020b) are distinctly different from the Skuggliberga volcanic rocks (Figs. 6D \& 7A, B).
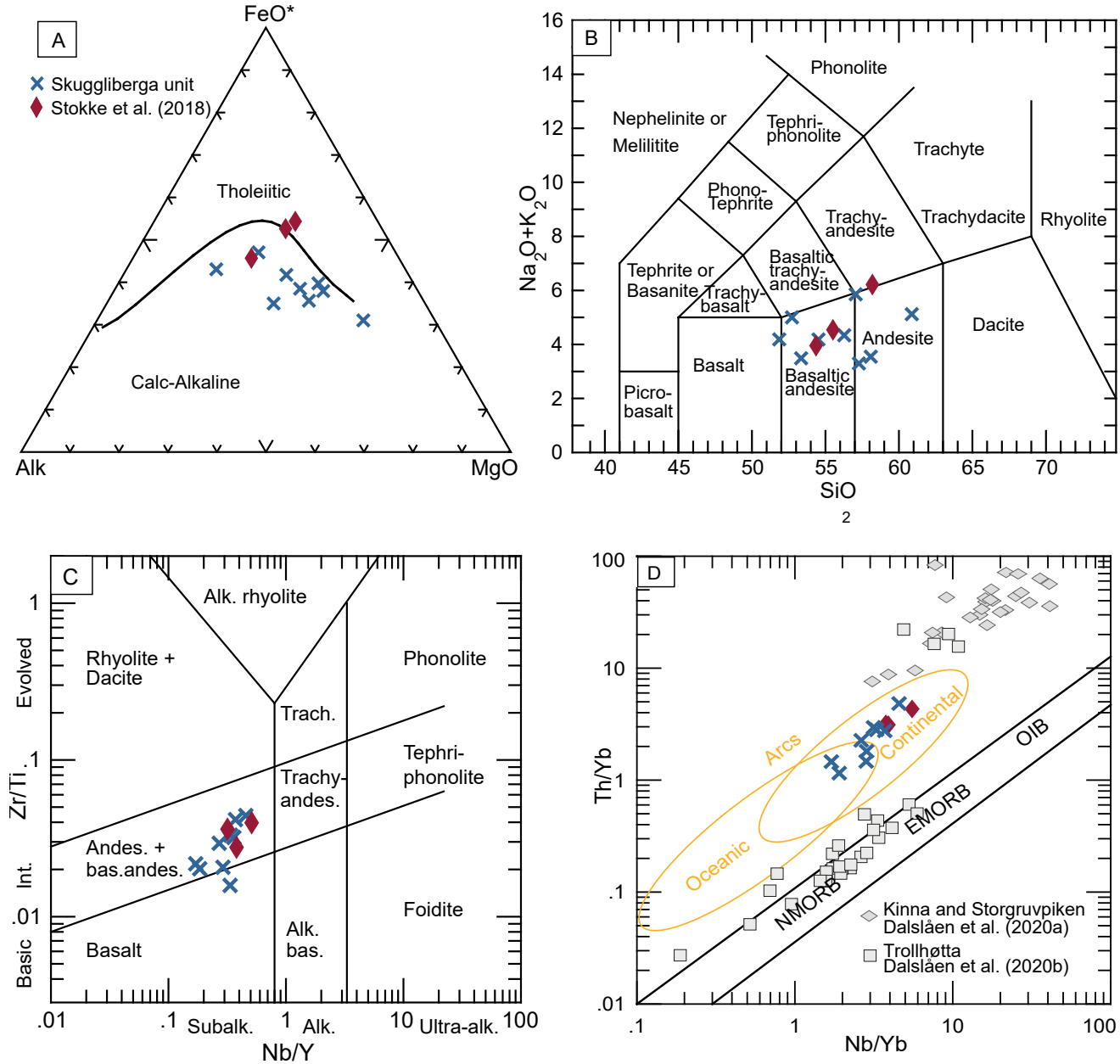

Figure 6. Discrimination diagrams for the Skuggliberga volcanic rocks; red diamonds are the volcanic rocks from Stokke et al. (2018). (A) AFM plot showing the calc-alkaline affinity. (B) TAS diagram and (C) Nb/Y vs. Zr/Ti plot (Pearce, 1996), both showing basaltic andesite and andesite compositions. (D) Nb/Yb vs. Th/Yb plot (Pearce, 2008) demonstrating continental-arc geochemical affinities. The compositional fields of Kinna and Storgruvpiken (grey diamonds; Dalslåen et al., 2020a) and Trollhøtta (grey squares, Dalslåen et al., 2020b) are shown for comparison. 
(A) Rock/N-MORB

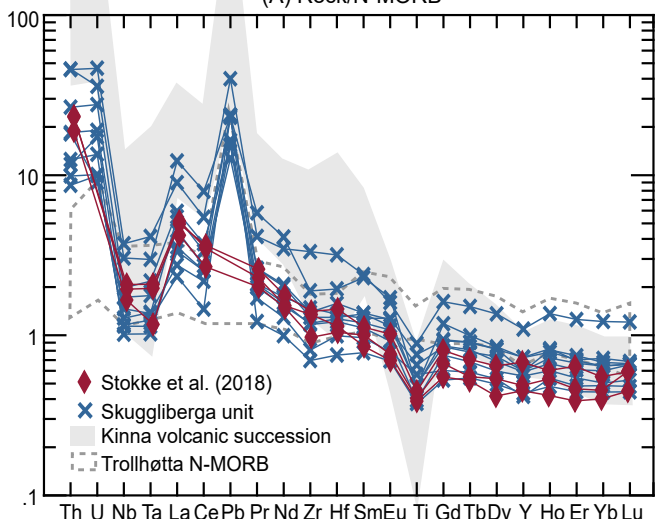

Th U Nb Ta La CePb PrNd Zr Hf SmEu Ti GdTbDy Y Ho Er Yb Lu

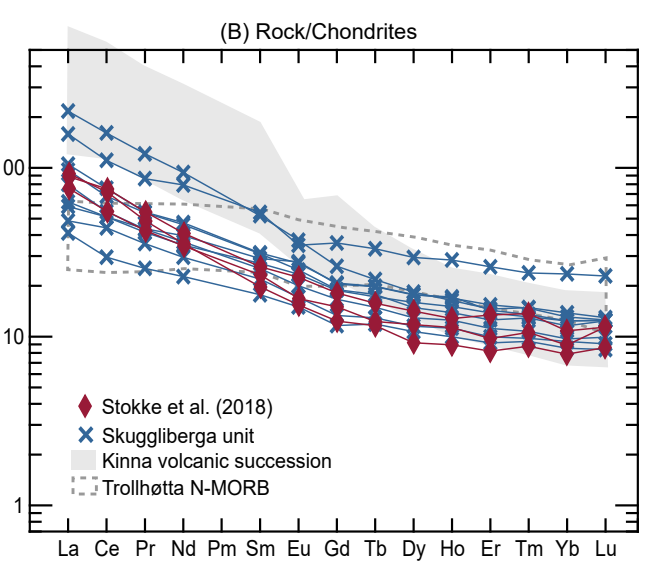

Figure 7. Multi-element plots for the Skuggliberga volcanic rocks. (A) MORB-normalised patterns; normalising values are from average N-MORB data of Gale et al. (2013). (B) Chondrite-normalised patterns; chondrite values from Sun \& McDonough (1989). The patterns of the Kinna volcanic succession (Dalsläen et al., 2020a) and the MORB-like mafic rocks of the Trollhøtta unit (Dalslåen et al., 2020b) are added for comparison.

\section{Geochronology}

Several attempts were made to directly date the volcanic rocks of the Skuggliberga unit. Unfortunately, the volcanic rocks we separated (with up to $137 \mathrm{ppm}$ of $\mathrm{Zr}$ ) did not contain zircon, monazite or other heavy minerals that could have provided an age of volcanism. To obtain at least a maximum depositional age of the Skuggliberga unit, two sandstone samples were selected for detrital zircon analysis. In addition, we analysed biotite from one volcanic sample by $\mathrm{Ar}-\mathrm{Ar}$ geochronology, which provides an age for the cooling following regional metamorphism.

\section{LA-ICP-MS analysis of detrital zircon}

\section{Method}

Three sandstone samples were selected for detrital zircon analysis, one from the directly underlying Skaret succession of the Skarvatnet unit (Dalslåen et al., 2020a), and two from the northern area of the Skuggliberga unit (Fig. 2A). The sample previously analysed by Stokke et al. (2018) from the small, northeastern sandstone area at Dugurdsknappen is included for comparison (Figs. 2A \& 8). The samples were processed at the University of Oslo. They were crushed using standard methods and washed on a Wilfley table. A hand magnet was used to remove strongly magnetic minerals. The zircons were separated using heavy liquids with a density of $2.80 \pm 0.02 \mathrm{~g} / \mathrm{ml}$. The separated grains were randomly picked, mounted in epoxy and examined with a combination of backscattered electron imaging and cathodoluminescence imaging prior to analysis. $\mathrm{U}-\mathrm{Pb}$ analyses were carried out by LA-ICP-MS, using a Nu Plasma HR multicollector mass spectrometer equipped with Cetac LSX-213 G2+ laser microprobe at the Department of Geosciences, University of Oslo. U-Pb analyses follow the analytical protocols of Andersen et al. (2009). Ablation conditions were beam diameter $40 \mu \mathrm{m}$ (aperture imaging mode) and pulse frequency $10 \mathrm{~Hz}$. An in-house spreadsheet was used for data reduction.

Only analyses with less than $\pm 10 \%$ central discordance are included in the following descriptions and plots. For plots of the Palaeozoic population and maximum depositional age calculations, only analyses with less than $\pm 5 \%$ central discordance are included, as we consider data less than $5 \%$ 

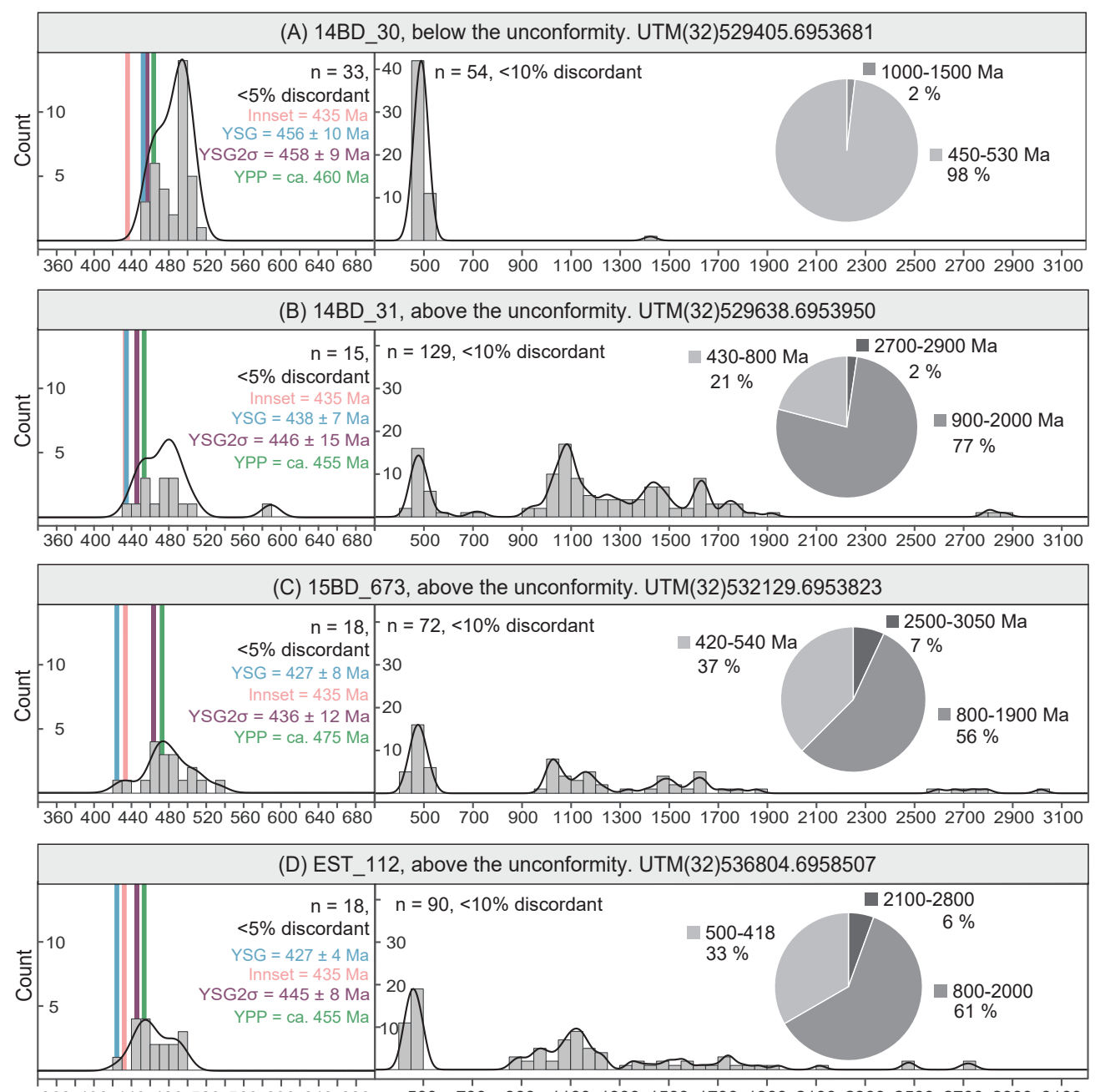

$360400440480520560600640680 \quad 500700900111001300150017001900210023002500270029003100$ Age (Ma)

$$
\text { Age (Ma) }
$$

Figure 8. Detrital zircon age spectra for four sandstone samples; combined histograms and kernel density estimates (KDE). All detrital zircon U-Pb age plots are made with the 'detzrcr software package for $R^{\prime}$ (Andersen et al., 2018). Band width $=10$ in the Caledonian populations, band width = 25 in the full spectra. The Caledonian populations are shown separately and represent data less than 5\% discordant, all other data shown are less than 10\% discordant. Thin pink bars in the Caledonian populations are the age of the Innset massif (435 Ma; Nilsen et al., 2003), blue bars represent the youngest single grain (YSG), purple bars are the calculated maximum deposition age based on the 3 youngest zircons with overlapping age at $2 \sigma(Y G C 2 \sigma)$, and the thin green bars are the youngest graphical peak (YPP).

discordant to be more robust for maximum depositional age calculations. For grains older than $1000 \mathrm{Ma}$ the ${ }^{207} \mathrm{~Pb} /{ }^{206} \mathrm{~Pb}$ age is reported, while for grains younger than $1000 \mathrm{Ma}$ the ${ }^{206} \mathrm{~Pb} /{ }^{238} \mathrm{U}$ age is reported. $1000 \mathrm{Ma}$ is chosen as a limit because only few grains are close to this age and it is preferable to avoid changing the parameters within an age fraction. All data are plotted as histograms with Kernel Density Estimates and cake plots in Fig. 8, and as upper quartile/lower quartile plots and cumulative distribution plots (Andersen et al., 2018) in Fig. 9. The full analytical dataset can be found in Electronic Supplement 1.

No common lead correction was applied to samples $14 \mathrm{BD}$ _31 and 15BD_673. For sample 14BD_30, a common lead correction was applied, as the majority of grains in this sample had high contents of common lead; 18 of the 54 reported analyses have been common lead-corrected following the procedure described in Andersen et al. (2009) using an in-house spreadsheet program. 

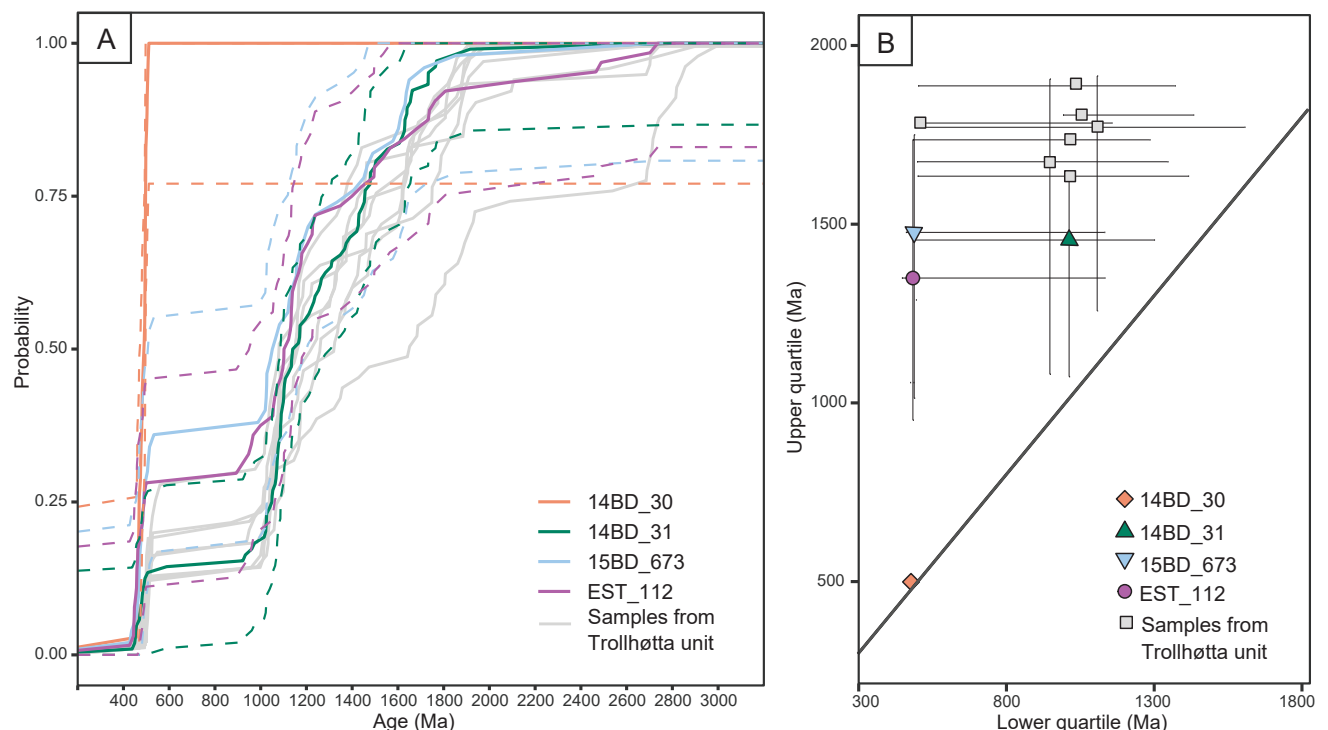

Figure 9. Detrital zircon data from sedimentary rocks of the studied area. (A) Plot of the cumulative distribution of zircon U-Pb ages (Andersen et al., 2018). Sample 14BD_30 from directly below the unconformity is clearly different from the samples above the unconformity. Samples from the Trollhøtta unit (Dalslåen et al., 2020b) are plotted in grey. Uncertainties are omitted for the Trollhøtta samples to increase readability of the diagram. (B) Upper/lower quartile plot of zircon U-Pb ages (Andersen et al., 2018), with Trollhøtta samples plotted in grey.

Detrital zircon datasets are commonly used to calculate a maximum depositional age (MDA) for the sedimentary rock in which the zircons occur. Multiple methods have been proposed for calculating a MDA, the most commonly used being the youngest single grain (YSG), the youngest grain cluster composed of three or more grains that overlap at $2 \sigma(\mathrm{YGC} 2 \sigma)$ and the youngest graphical peak (YPP; e.g., Dickinson \& Gehrels, 2009; see a summary of several methods in Coutts et al., 2019). There is no recommendation for discordance filtering included in the description of these methods (Dickinson \& Gehrels, 2009), but we apply a 5\% central discordance filter for our Palaeozoic age fractions used for MDA calculation.

\section{Results}

Sample 14BD_30 is a grey granule conglomerate with a biotite-rich carbonaceous matrix, belonging to the Skaret succession of the Skarvatnet unit and sampled stratigraphically directly below the unconformable contact to the northern part of the Skuggliberga unit (Dalslåen et al., 2020a; Fig. 2A). 92 grains were analysed, 54 of which were $<10 \%$ discordant. Except for one grain at $1423 \pm 12$ Ma (- 8.3\% discordant, Figs. 8A \& 9), this sample has an exclusively Ordovician to Cambrian (450-530 $\mathrm{Ma}$ ) zircon population with a major peak at c. $490 \mathrm{Ma}$ (Fig. 8A). The different methods to estimate the MDA give $456 \pm 10 \mathrm{Ma}$ (YSG, $-0.1 \%$ discordant), $458 \pm 9 \mathrm{Ma}$ (YGC 2 $\sigma$ ) and c. $460 \mathrm{Ma}$ (YPP).

Sample 14BD_31 is a cross-stratified sandstone from the western part of the northern Skuggliberga unit (Fig. 2A). The sample has abundant zircon. 149 zircons were analysed, of which 129 were $<10 \%$ discordant. The sample consists of $2 \%$ Archaean grains (2700-2900 Ma), 77\% Neo- to Palaeoproterozoic grains (900-2000 Ma) and 21\% Silurian to Cambrian grains (430-800 Ma, Figs. 8B \& 9). The Cambrian-Silurian analyses are spread between 430 and $500 \mathrm{Ma}$ with one grain at $580 \mathrm{Ma}$. The different methods to estimate the MDA give $438 \pm 7 \mathrm{Ma}$ (YSG, 2.8\% discordant), $446 \pm 15 \mathrm{Ma}$ (YGC 2б) and c. $455 \mathrm{Ma}$ (YPP). 
Sample 15BD_673 is a cross-stratified sandstone from the southeastern part of the northern Skuggliberga deposit, where it overlies the massive conglomerate (Fig. 2A). The sample has abundant zircon and 125 grains were analysed, of which 72 were $<10 \%$ discordant. The sample consists of $7 \%$ Archaean grains (2500-3050 Ma), 56\% Neo- to Palaeoproterozoic grains (800-1900 Ma) and 37\% Silurian to Cambrian grains (430-540 Ma, Figs. 8C \& 9). The different methods to estimate the MDA give $436 \pm 8 \mathrm{Ma}$ (YSG, $0.3 \%$ discordant), $463 \pm 12 \mathrm{Ma}$ (YGC 2 $\sigma$ ) and c. $475 \mathrm{Ma}$ (YPP).

Sample EST112 is a cross-stratified sandstone from the small preserved deposits east of the main, northern Skuggliberga area, and has previously been analysed for detrital zircon by Stokke et al. (2018). In order to compare the results from this sample with our new data, it is plotted in the same way as our new samples in Figs. 8D \& 9. One hundred zircons were analysed, of which 91 were $<10 \%$ discordant. The sample consists of $6 \%$ Palaeoproterozoic to Neoarchaean grains (2100-2800 Ma), $61 \%$ Neo- to Palaeoproterozoic grains (800-2100 Ma), and 33\% Silurian to Cambrian grains (418-500 Ma). The different methods to estimate the MDA give $427 \pm 4 \mathrm{Ma}$ (YSG, $4 \%$ discordant), $445 \pm 8 \mathrm{Ma}$ (YGC 2 $\sigma$ ) and c. $455 \mathrm{Ma}$ (YPP).

\section{Ar-Ar dating of biotite}

\section{Method}

We separated biotite from a fine-grained fragment with subhedral biotite from sample 15BD_152 (Fig. 4E, F) to obtain an age of the Caledonian metamorphism in the Oppdal area. The sample was crushed and sieved to obtain 180-250 $\mu \mathrm{m}$ fractions. The finer particles were decanted in tap water and the coarser residue further ultrasonically washed in acetone and deionised water several times. The optically best biotite grains, void of any coatings and inclusions, were hand-picked under a stereomicroscope. The sample was packed in an aluminum capsule together with the PP20 fluence monitor standard along with zero-age reagent-grade $\mathrm{K}_{2} \mathrm{SO}_{4}$ and optical grade $\mathrm{CaF}_{2}$ salts for interference corrections. We calculated J-values relative to an age of $1080.4 \pm 1.1 \mathrm{Ma}$ for the PP20 hornblende fluence monitor (Renne et al., 2010). The sample was irradiated at the BNC reactor

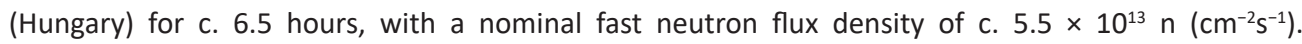
The interference correction factors for the production of isotopes from $\mathrm{Ca}$ and $\mathrm{K}$ are presented in Electronic Supplement 2. The rest of the analytical procedure follows Vissers et al. (2020).

\section{Result}

The degassing spectrum and inverse isochron results from sample 15BD_152 are displayed in Fig. 10 while the main results can be found in Table 2. The degassing experiment displays a flat release spectrum for $100 \%$ cumulative released ${ }^{39} \mathrm{Ar}$ from which an inverse error weighted mean of $416.3 \pm 3.2$ Ma was calculated. The inverse isochron result overlaps with the plateau age and the trapped ${ }^{40} \mathrm{Ar} /{ }^{36} \mathrm{Ar}$ estimate overlaps with modern air composition (Lee et al., 2006) so we use the plateau age of $416 \pm 3$ $\mathrm{Ma}$ as the best age estimate of these biotites in the following discussion.

Table 2. Main results from Ar-Ar biotite geochronology. TGA - total gas age, MSWD (P) is the mean squared weighted deviations and probability of fit.

\begin{tabular}{|c|c|c|c|c|c|c|c|c|c|c|c|c|c|}
\hline \multirow[b]{2}{*}{ Sample } & \multirow[b]{2}{*}{ Material } & \multirow[b]{2}{*}{ Lat } & \multirow[b]{2}{*}{ Long } & \multirow[b]{2}{*}{$\begin{array}{c}\text { Steps } \\
\text { (n) }\end{array}$} & \multicolumn{5}{|c|}{ Spectrum } & \multicolumn{4}{|c|}{ Inverse Isochron } \\
\hline & & & & & $\%^{39} \mathrm{Ar}$ & $\begin{array}{l}\text { Age } \pm \\
1.96 \sigma\end{array}$ & $\begin{array}{c}\text { MSWD } \\
(P)\end{array}$ & $\begin{array}{l}\text { TGA } \pm \\
1.96 \sigma\end{array}$ & $\begin{array}{c}\mathrm{K} / \mathrm{Ca} \pm \\
1.96 \sigma\end{array}$ & $\begin{array}{l}\text { Age } \pm \\
1.96 \sigma\end{array}$ & $\begin{array}{c}\text { MSWD } \\
(P)\end{array}$ & $\begin{array}{l}\text { Trapped } \\
{ }^{40} \mathrm{Ar} /{ }^{36} \mathrm{Ar}\end{array}$ & $\begin{array}{c}\text { Spread } \\
(\%)\end{array}$ \\
\hline 15BD_152 & Biotite & 62.73979 & 9.625941 & $\begin{array}{l}1-27 \\
(27)\end{array}$ & 100 & $\begin{array}{r}416.29 \\
\pm 3.24\end{array}$ & $\begin{array}{c}0.65 \\
(0.91)\end{array}$ & $\begin{array}{r}415.12 \\
\pm 3.69\end{array}$ & $\begin{array}{c}0.72 \pm \\
2.27\end{array}$ & $\begin{array}{c}417.42 \\
\pm 3.39\end{array}$ & $\begin{array}{c}0.59 \\
(0.95)\end{array}$ & $\begin{array}{c}289.84 \pm \\
11.19\end{array}$ & 90.4 \\
\hline
\end{tabular}



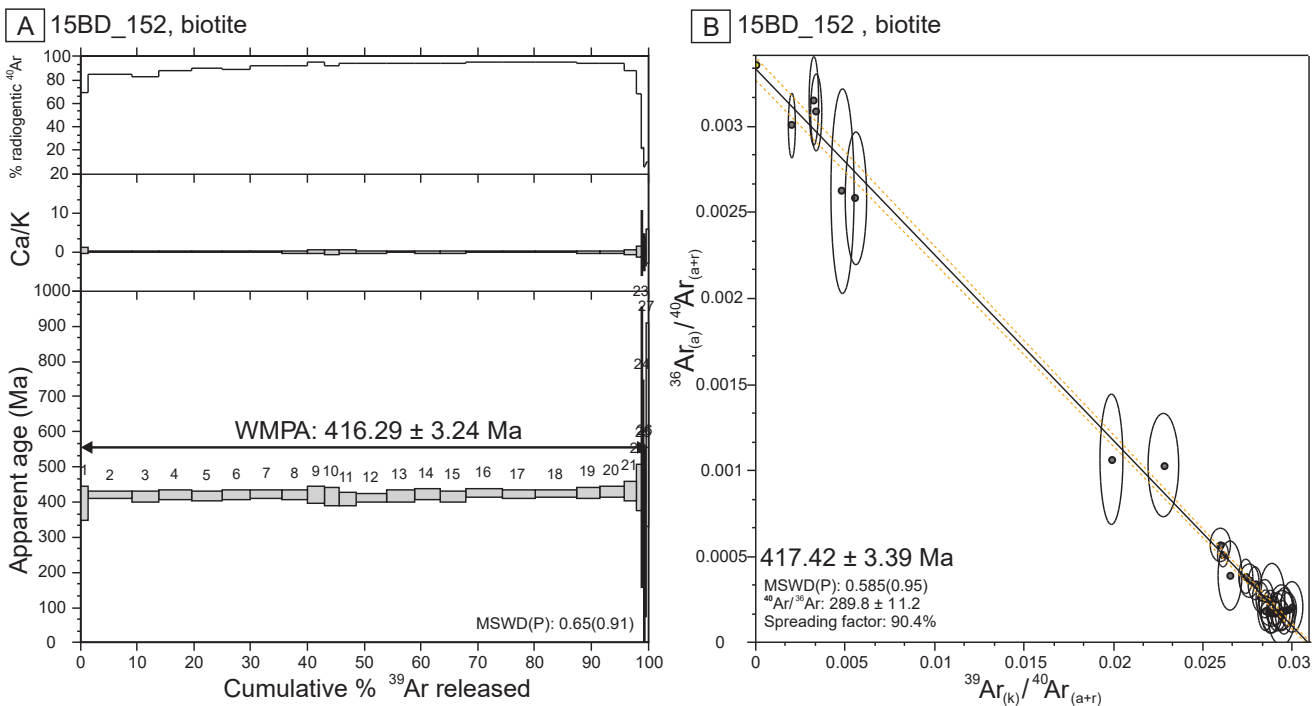

Figure 10. (A) Ar-Ar degassing spectrum. (B) Inverse isochron results for sample 15BD_152.

\section{Discussion}

\section{Depositional environment and source of the Skuggliberga sedimentary rocks}

The polymictic conglomerate in the northern area was deposited unconformably on the deformed Trollhøtta unit, and no clasts of Skuggliberga volcanic rocks are observed. This indicates that Skuggliberga volcanism was not active yet at the time of deposition of the conglomerate, and we therefore interpret it as representing the oldest deposit within the Skuggliberga unit. Many clasts within this conglomerate are from rock types present in the underlying Trollhøtta and Kinna units, and especially the presence of Kinna-type clasts is a strong indication of a significant local source. On the other hand, granite, quartzite and limestone clasts have no known source in exposed underlying units and indicate the presence of more long-travelled material. Except for a faint bedding, there are no internal structures preserved that can give unequivocal clues to the depositional environment of the conglomerate, but given the clast size, a river or beach deposit is most likely. The much thinner conglomerate beds preserved in the southern Skuggliberga area are dominated by clasts derived from Skuggliberga volcanic rocks, indicating local deposition contemporaneous with volcanism.

The cross-stratified to massive sandstones that overlie the polymictic conglomerate or are deposited directly upon Trollhøtta rocks, are immature to sub-mature and poorly sorted and have probably undergone limited transport. This indicates proximal, shallow-water deposition. Cross-stratified varieties suggest a depositional environment such as a meandering river or shallow-marine deposition above the wave base on a tidal flat. The lack of enclosing, clearly marine sediments (mudstone, limestone) indicate a fluvial setting, although a marine setting cannot be completely ruled out. The change from cross-stratified to planar-bedded and more massive, structureless sandstones up section could reflect a change in water depth or stream velocity, increased sediment input, or a combination of these. 
The detrital zircon spectra from the two sandstone samples above the unconformity indicate sediment contributions from two main sources: (1) a Cambro-Ordovician source, probably derived from subduction, and arc-related lapetus rocks equivalent to those in regionally underlying successions; and (2) an Archaean to Neoproterozoic continental source (in agreement with the character of some of the conglomerate clasts) or recycling of material derived from such a source. These age spectra contrast with those of sandstone sample 14BD_30 from directly below the unconformity, which is sourced entirely from Cambro-Ordovician source rocks in agreement with the volcanic-dominated detritus in the Skaret succession. The latter consists of a variety of chaotic volcanic-derived conglomerates with partly carbonaceous matrix, indicating deposition on unstable slopes of volcanic islands (Dalslåen et al., 2020a). The detrital zircon spectra from the Skuggliberga sandstones are comparable with the detrital zircon spectra from sandstones of the Trollhøtta unit (Fig. 9; Dalslåen et al. 2020b), but samples 15BD_673 and EST_112 (and one Trollhøtta sample) have a larger proportion of Palaeozoic zircon and plot at younger lower quartile ages compared to the Trollhøtta samples (Fig. 9B). Even though the Skuggliberga sandstones seemingly have a larger fraction of juvenile material, the detrital zircon spectra indicate input from similar sediment sources as during Trollhøtta sedimentation and/or recycling of Trollhøtta sedimentary rocks into the Skuggliberga basin.

\section{Depositional environment and tectonic setting of the Skuggli- berga volcanic rocks}

Identifying the nature and depositional environment of the Skuggliberga volcanic rocks is not straightforward due to the regional metamorphic overprint and limited outcrop quality. Stokke et al. (2018) mentioned that the volcanic rocks might represent sheets within the sandstones, possibly indicating that parts of the volcanic rocks could represent shallow intrusions. However, our observations of fragment-bearing, fine-grained, massive and vesicular varieties lead us to conclude that most of the volcanic rocks probably represent primary volcanic surface deposits.

The Skuggliberga volcanic deposits are basaltic andesites and andesites (Fig. 6B), rock types that may be associated with both explosive and effusive eruptions and a wide range of depositional styles. Basaltic andesites commonly form channellised aa lava flows, which typically are 2-20 m thick with a massive core and a layer of clinker (fragmented crust of the lava flow) at the top and the bottom (e.g., Cas \& Wright, 1988; Rowland \& Walker, 1990). By contrast, andesites commonly form lava flows that are shorter and thicker and covered in blocky fragments; pyroclastic deposits are more common. The angular to subangular fragments in the Skuggliberga volcanic rocks and the alternation between fragment-bearing and massive parts could be interpreted both in terms of lava flows and as pyroclastic rocks. The massive, fragment-free parts could represent central parts of lava flows sandwiched between layers of fragmented and welded clinker, or the deposits could be pyroclastic rocks where the fragments are intraformational/cognate lithic fragments (e.g. Cas \& Wright, 1988).

Several observations indicate that the Skuggliberga volcanic rocks represent pyroclastic deposits rather than lava flows: (1) the fragments are scattered and dispersed in the matrix, which would not be the case if the fragments had formed during autobrecciation of the outer part of a lava flow; aa and blocky lavas commonly form rubbly, fragment-supported layers at the top and base of the flow. (2) The fragments are more abundant and larger in the northern part of the northern area, while smaller, fewer clasts and local beds of greenish, probably volcanic-derived sandstone characterise the southern area. This indicates that the northern part might have been more proximal to the eruption site, while the southern part was more distal and therefore dominated by finer-grained pyroclastic or even volcaniclastic material. (3) The Skuggliberga volcanic rocks are porphyritic with phenocrysts 
of biotite and amphibole, and the phenocrysts are typically larger in the fragments compared with the matrix and fragment-free parts. Such systematic variation in grain size could result from explosive eruptions with a high fragmentation rate, either during eruption or during subsequent transport, the smaller biotite and amphibole in the matrix and in the fragment-free deposits representing broken phenocrysts. This variation in phenocryst size between fragments and matrix cannot be explained in terms of autobrecciation of a lava flow. In other areas, phenocrysts are seemingly preserved in the fragment-free parts; this suggests that some eruptive phases were less violent. Unfortunately, smallscale structures are destroyed by metamorphism, which makes an interpretation of the eruptional and depositional style difficult. This is especially valid for thin-section analysis, as the fine-grained epidote overgrowths and advanced alteration of feldspars make it difficult to assess whether the varying phenocryst size is a primary magmatic feature or resulted from fragmentation during eruption and subsequent transport.

Locally observed volcanic-derived sandstones between the volcanic rocks indicate that eruption and deposition was probably episodic and occurred in a terrestrial (fluvial) or shallow-marine environment. The sand beds indicate periods of erosion and redeposition of the volcanic rocks within the volcanic succession. An episodic eruption style with a volcanic centre to the north is also supported by the volcanic fragments within the sandstone below the southern volcanic deposit; the southern sandstone must have been deposited during or after volcanic activity started in the north.

The geochemical composition of the Skuggliberga volcanic rocks is clearly different from the underlying MORB-like basaltic rocks of the Trollhøtta unit as well as the extremely enriched volcanic rocks of the Skarvatnet unit (Figs. 6D \& 7; Dalslåen et al. 2020a, b). The andesitic composition and the trace element signature of the Skuggliberga volcanic rocks both suggest a volcanic arc environment; especially the negative $\mathrm{Nb}-\mathrm{Ta}$ anomaly and the flat pattern from $\mathrm{Y}$ to $\mathrm{Lu}$ in MORB-normalised plots (Fig. 7A) are common features of arc-related volcanic rocks (e.g., Pearce \& Peate, 1995; Hermann \& Rubatto, 2009). As demonstrated by the Th/Yb vs. Nb/Yb diagram (Fig. 6D), the volcanic rocks are also akin to continental rather than oceanic arcs, making a continental arc setting most likely.

\section{The age of the Skuggliberga unit}

Stokke et al. (2018), who first described the rocks of the Skuggliberga unit, concluded with a post-427 Ma age for the cross-stratified sandstone and the volcanic rocks in the western part of the northern area (Fig. 2A), suggesting that the Skuggliberga unit might represent a hitherto unknown Silurian volcanic phase within the Scandinavian Caledonides. This age estimate was based on a MDA YGC2 $\sigma$ calculation, using the five youngest grains less than $10 \%$ discordant, of which four were $5-10 \%$ discordant. By using a more rigorous 5\% discordance filter as in the current study, the EST112 sample from Stokke et al. (2018) gives an older MDA of $446 \pm 5$ Ma by the YGC2 $\sigma$ method.

The post-427 Ma age suggestion of Stokke et al. (2018) is in conflict with our new field observations from the southern area, where the Skuggliberga volcanic rocks were intruded by granodiorite of the Innset massif dated at 434.8 $\pm 0.5 \mathrm{Ma}$ and $435.8 \pm 0.9 \mathrm{Ma}$ (Nilsen et al., 2003), indicating that the Skuggliberga unit is older than $435 \mathrm{Ma}$. MDA calculations based on $<5 \%$ discordant data and using the YGC2 $\sigma$ and YPP approach agree with this information (Fig. 8), whereas MDA estimates based on YSG are too young (the YSG MDAs overlap in age with the Innset intrusion, Fig. 8).

A common problem with MDA calculation based on detrital zircon data, particularly in datasets where the ages of near-depositional grains and metamorphism are close, is that undetected lead loss can lead to MDA estimates younger than the true depositional age (e.g., Andersen et al., 2019; Coutts et al., 2019). Andersen et al. (2019) presented theoretical considerations and practical examples showing 
that even when applying a discordance filter of 5 or $10 \%$, the remaining near-concordant grains may have suffered undetected lead loss. Such grains can represent any combination of upper and lower intercept ages and degrees of lead loss that keeps the analysis inside the $5 \%$ or $10 \%$ discordance envelope. Processes that potentially result in lead loss in detrital zircons at a certain point after deposition include diagenetic fluids, regional metamorphism and contact metamorphism (e.g., Andersen, 2013; Andersen et al., 2019).

Following the reasoning of Andersen et al. (2019), the five $<10 \%$ discordant grains used by Stokke et al. (2018) to define a MDA of 427 Ma for the Skuggliberga sandstone could represent older grains that experienced undetected lead loss at some point in time. An obvious candidate for a lead loss event might be the regional metamorphism represented by the c. 416 Ma cooling age as indicated by the $\mathrm{Ar}-\mathrm{Ar}$ age of biotite. Basically, any Cambro-Ordovician (500-460 Ma) zircon affected by lead loss at $416 \mathrm{Ma}$ would stay within the $5 \%$ discordance envelope due to the weak curvature of the concordia curve during this time interval. Similarly, a c. 1100 Ma zircon, which represents an age peak in our samples, could be moved to near concordia at $427 \mathrm{Ma}$ by considerable lead loss at $416 \mathrm{Ma}$. We therefore consider the interpretation of a post-427 Ma age for the Skuggliberga unit as being based on a spurious detrital zircon age fraction probably caused by undetected lead loss. We consider the field observation of the Innset massif intruding the Skuggliberga volcanic rocks as more robust, demonstrating that the unit is older than $435 \mathrm{Ma}$.

The maximum age of the Skuggliberga unit is constrained by the age of the underlying deformed volcanic rocks of the Trollhøtta and Skarvatnet units, which have extrusion ages of c. 475-470 Ma (Dalslåen et al., 2020a, b). The most conservative MDA estimates (YPP) from three separate samples are still up to $15 \mathrm{Myr}$ younger than the ages of the underlying volcanic units $(455,475$ and $455 \mathrm{Ma}$ for samples 14BD_31, 15BD_673, and EST112, respectively). However, when pooling all Palaeozoic $<5 \%$ discordant analyses from the three samples, the youngest graphical peak estimate (YPP) becomes $475 \mathrm{Ma}$ (Fig. 11), which corresponds to the age of the underlying volcanic units. This illustrates how sample size and chosen MDA method greatly influences the resultant MDA estimate (Coutts et al., 2019). It is noteworthy that 17 analyses are still included in histogram bins younger than the YPP (Fig. 11), and many other MDA methods based on the youngest grains therewith would deliver considerably younger MDAs. We consider it likely that those younger grains might hide undetected lead loss similar to the grains used by Stokke et al. (2018), but an origin from younger (e.g., 470-450 Ma) protosources cannot be excluded completely. In order to assess the likelihood of magmatic protosources in the age range 470-450 Ma and to constrain the most likely time of deposition for the Skuggliberga unit, a comparison with Middle Ordovician to early Silurian magmatic and sedimentary rocks elsewhere in the Scandinavian Caledonides is attempted below.

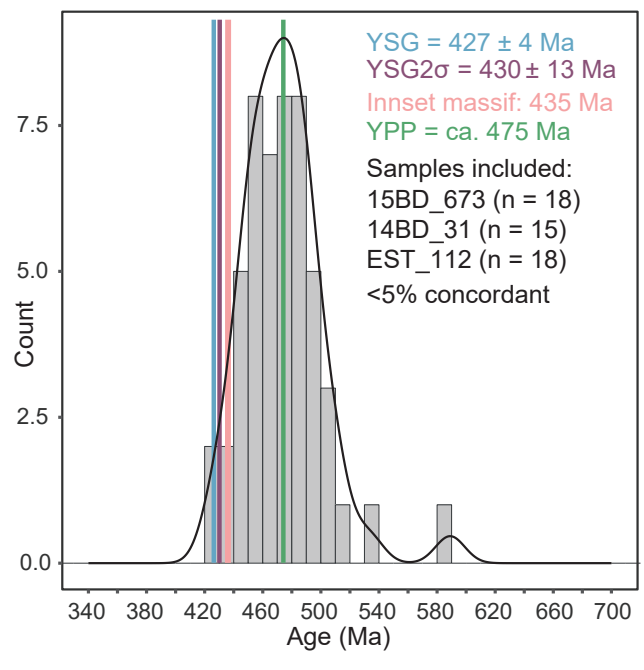

Figure 11. Pooled histogram and kernel density estimates (KDE) of all $<5 \%$ discordant grains from samples 14BD_31, 15BD_673 and EST_112, showing that the youngest graphical peak is at $475 \mathrm{Ma}$ corresponding to the age of the underlying volcanic rocks. 


\section{Comparison of the Skuggliberga unit with other Middle Ordovician to early Silurian rocks in the Scandinavian Caledonides}

On the map of Nilsen \& Wolff (1989), the northern part of the Skuggliberga unit was correlated with the Hovin Group of the TNC south of Trondheim. Originally defined as Lower and Upper Hovin Series (Vogt, 1945), the Hovin Group contains fossils of Middle and Late Ordovician age (470-445 Ma; e.g., Ryan et al., 1980; Neuman \& Bruton, 1989; Neuman et al., 1997). Two major volcanic episodes have been documented within the Hovin Group: (1) the older Hølonda Porphyrites, represented by basaltic to andesitic rocks of shoshonitic affinity (e.g., Grenne \& Roberts, 1998), which are associated with late Arenig/early Llanvirn (c. 467-463 Ma) fossiliferous limestone and shale (Neuman \& Bruton, 1989) and (2) the younger rhyolites and rhyolitic tuffs of the Høgknippen, Hårråklett and Grimsås areas, which are associated with late Caradoc/early Ashgill (c. 453-445 Ma) fossiliferous limestones (Vogt, 1945; Ryan et al., 1980; Neuman et al., 1997). None of these two volcanic units is lithologically or geochemically similar to the Skuggliberga volcanic rocks, and limestones are totally missing in the Skuggliberga unit. A direct correlation to any part of the Hovin Group rocks farther north is therefore unlikely. However, the volcanic rocks of the Hovin Group could possibly represent protosources for detrital zircons in the age range 467-445 Ma, potentially delivering some of the $<470 \mathrm{Ma}$ detrital grains observed in the Skuggliberga unit.

Based on the age data provided in Stokke et al. (2018), Roberts et al. (2019) suggested that the Skuggliberga unit may correlate with the Ekne Group northeast of Trondheim (Fig. 1A). Four detrital zircon samples from the Ekne Group are dominated by Palaeozoic detrital zircons which show main peaks at $460-450 \mathrm{Ma}$, interpreted by Roberts et al. (2019) to indicate deposition in the Late Ordovician to Silurian. However, the Ekne Group is lithologically different from the Skuggliberga unit, as it is dominated by turbiditic sandstones and siltstones and does not contain volcanic rocks. The Palaeozoic-dominated detrital zircon signature of the Ekne Group is also very different from the more diverse signature of the Skuggliberga unit. Therefore, a direct correlation of the Ekne Group with the Skuggliberga unit is unlikely.

Post-470 Ma volcano-sedimentary successions are known from the Scandinavian Caledonides both south and north of the TNC. South of the TNC, the Karmøy-Bømlo-Bergen arc area (Fig. 1A) contains late Cambrian to Early Ordovician SSZ ophiolites overlain by Early Ordovician (c. 476-473 Ma) volcanic rocks (the Kattnakken and Siggjo complexes), which were deformed prior to deposition of fossiliferous Late Ordovician to early Silurian volcano-sedimentary successions (e.g., Dunning \& Pedersen, 1988). The Vikafjord Group of Bømlo, deposited unconformably on deformed Siggjo volcanic rocks, consists of alluvial to shallow-marine sediments succeeded by subaerial basaltic, calc-alkaline volcanic rocks (Nordås et al., 1985). Fossils in the Vikafjord Group indicate a depositional age of c. 450-433 Ma (Nordås et al., 1985), in agreement with the possible depositional age span for the Skuggliberga unit. The similar association of fluvial to shallow-marine sedimentary and calc-alkaline volcanic rocks makes a correlation with the Skuggliberga unit reasonable. The Os Group of the Bergen arc area, resting unconformably on the Gullfjellet ophiolitic fragment, contains Late Ordovician to early Silurian fossils and comprises polymictic conglomerate overlain by shale, minor limestone and cross-stratified sandstone, but lacks volcanic rocks like those of the Vikafjord and Skuggliberga units (Ingdahl, 1989). The Late Ordovician (c. $443 \mathrm{Ma}$ ) Solund-Stavfjord ophiolite complex falls within the same time span (Furnes et al., 2012). It is dominated by N-MORB-type lavas with only a weak subduction influence, but arc-related, early Silurian (c. $439 \mathrm{Ma}$ ) mafic to felsic volcanic rocks also occur (Furnes \& Lippard, 1983; Hartz et al., 2002), possibly representing time-equivalents to the Skuggliberga volcanic rocks. 
North of the TNC, the Sulitjelma area (Fig. 1A) contains remnants of a marginal basin with an E-MORB type gabbro-basalt complex (Sulitjelma), overlain by the fossiliferous Late Ordovician to early Silurian Furulund Group that contains calc-alkaline (Lomivann) basaltic rocks (Boyle, 1989; Pedersen et al., 1991). This basin has been correlated with the Solund-Stavfjord basin and also represents a marginal basin that is potentially correlatable with the Skuggliberga unit in terms of age and depositional-volcanic environment. Even farther north, Late Ordovician to early Silurian turbidites and local carbonate and volcanic rocks are known from the Sagelvvatn Group (Fig. 1A; Bjørlykke \& Olaussen, 1981) and from the Oksfjord Group (Fig. 1A; Lindahl et al., 2005). However, both groups contain basaltic lava flows with tholeiitic within-plate type geochemical affinities, different from the calc-alkaline nature of the Skuggliberga andesites. Finally, the Magerøy Supergroup of Late Ordovician to early Silurian age in northern Norway (Fig. 1A) was intruded-similar to the Skuggliberga unit-by a major $438 \pm 1 \mathrm{Ma}$ composite plutonic complex (Andersen, 1981; Corfu et al., 2006). However, the Magerøy Supergroup is composed entirely of shallow- to deep-marine turbiditic and calcareous rocks and does not contain volcanic rocks.

Middle Ordovician to early Silurian continental arc-related plutonic complexes are common from Smøla and Hitra in the south to the Helgeland Nappe Complex and correlatives farther north (Fig. 1A). Magmatic activity stretches from c. $482 \mathrm{Ma}$ to c. $424 \mathrm{Ma}$ and is considered to result from subduction under the Laurentian margin (Tucker et al., 2004; Barnes et al., 2007; Barnes et al., 2011; Augland et al., 2012; Slagstad \& Kirkland, 2018). Like the Skuggliberga volcanic rocks, many of these complexes have arc-like geochemical signatures, e.g., the 440-445 Ma Smøla-Hitra Batholith (Gautneb \& Roberts, 1989; Tucker et al., 2004), the $456 \pm 2$ Ma Møklevatnet monzodiorite (Meyer et al., 2003) and the $460 \pm 3$ Ma Follafoss tonalite (Tucker et al., 2004; Hollocher et al., 2016). They are also broadly comparable to the 460-440 Ma 'younger arc rocks' of Hollocher et al. (2016), a suite of metamorphic and deformed intrusive rocks exposed along the central Norwegian coast that were assigned to the Trondheim Nappe Complex. Given that the Skuggliberga volcanic rocks are geochemically comparable both to older and younger arc-related plutonic rocks, such a comparison does not allow further constraints on the age of the Skuggliberga unit within the 470-435 Ma time frame, but generally highlights the genetic link between the plutonic continental-arc complexes and the Skuggliberga unit. Circa 438-434 Ma bimodal mafic-felsic intrusive complexes comparable to the Innset massif can be found all along the Scandinavian Caledonides and have been interpreted to have formed in localised extensional basins at the onset of the Laurentia-Baltica collision (Nilsen et al., 2007; Slagstad \& Kirkland, 2018).

\section{The Pre-Skuggliberga orogenic event}

The Skuggliberga unit has been deposited on the folded and eroded Skarvatnet and Trollhøtta units, indicating the presence of a deformation phase between the formation of the Skarvatnet and Trollhøtta units (formation age c. 475-470 Ma; Dalslåen et al., 2020a,b) and deposition of the Skuggliberga unit. This orogenic phase is represented by deformation phases $D_{1}$ and $D_{2}$ of Stokke et al. (2018), and is regionally represented by tilting and overturning of the succession towards west (Fig. 2B). Constraining the age of this deformation phase is hampered by the uncertain depositional age of the Skuggliberga unit, but assuming a depositional age of c. 450-435 Ma-by analogy with the Vikafjord Group-the deformation phase must have happened between ca. 470 and $450 \mathrm{Ma}$.

Palaeogeographically this deformation phase can be constrained by the link between the Trollhøtta-Kinna rocks and the Støren and Hølonda rocks farther north. The deformed Trollhøtta unit has been correlated with the Støren sensu stricto basaltic rocks (Stokke et al., 2018; Dalslåen et al., 2020b), and the Kinna volcanic succession has geochemical similarities with the Hølonda Porphyrites (Grenne \& Roberts, 1998; Dalslåen et al., 2020a). The Hølonda Porphyrites are coeval with 
deposition of limestone with a Laurentian fauna (Neuman \& Bruton, 1989) placing formation of the Trollhøtta-Kinna and Støren-Hølonda systems close to the Laurentian margin. The connection to Laurentia is strengthened by the detrital zircon signature of the Trollhøtta unit (Dalslåen et al., 2020b). Dalslåen et al. (2020a) proposed that the onset of proper subduction under the Laurentian margin within the mid-Norwegian sector is marked by the voluminous arc magmatism that started at c. 460 Ma (e.g. Tucker et al., 2004). This could have caused accretion of the Trollhøtta-Kinna basin to the Laurentian margin or an associated microcontinent, causing the deformation of the rocks. Ordovician accretionary events, generally correlated with the Laurentian Taconian orogeny, are well known from the Helgeland Nappe Complex farther north (e.g., Yoshinobu et al., 2002; Roberts et al., 2002, 2007) and from the Appalachians in Newfoundland (e.g., van Staal et al., 2009), but the lack of a definite age of the Skuggliberga volcanic rocks hampers further correlation of events.

\section{Conclusions}

The Skuggliberga unit of the Oppdal area represents a distinct volcano-sedimentary unit within the southern Trondheim Nappe Complex. It was deposited unconformably upon the deformed c. 475-470 Ma Trollhøtta and Skarvatnet units and was intruded by the Innset massif at c. $435 \mathrm{Ma}$. The Skuggliberga unit consists of polymictic conglomerate and cross-stratified to massive sandstone, as well as calc-alkaline basaltic andesites and andesites. The sedimentary rocks indicate deposition in a fluvial or shallow-marine environment. The volcanic rocks most likely represent pyroclastic deposits. Detrital zircon spectra from three sandstone samples of the Skuggliberga unit are dominated by Archaean to Neoproterozoic grains, with a limited number of Palaeozoic grains. Spuriously young detrital zircon grains (<435 Ma) are probably the result of undetected lead loss of Early Palaeozoic grains caused by greenschist-facies metamorphism preceeding an Ar-Ar cooling age of c. $416 \mathrm{Ma}$. The possibility of undetected lead loss in the youngest detrital zircons means that the Palaeozoic detrital zircon grains cannot be used to constrain the maximum age of deposition any further. Comparison with other Middle Ordovician to early Silurian volcano-sedimentary units within the Scandinavian Caledonides suggests that the Skuggliberga unit has most in common with Upper Ordovician to early Silurian (ca. 450-435 Ma) units such as the Vikafjord Group of Bømlo, the Solund-Stavfjord ophiolite complex, or the Furulund Group of the Sulitjelma area. Our data imply that the unit has no direct correlative within the TNC and represents a hitherto unknown volcano-sedimentary phase within the Central Norwegian Caledonides. However, it has geochemical similarities with several continental arc-related plutonic complexes spanning the same age interval along the coastal area of central Norway, and the Skuggliberga volcanic rocks may represent an extrusive part of this magmatic arc system. Deposition of the Skuggliberga units is preceded by an orogenic phase resulting in deformation of the underlying Trollhøtta and Skarvatnet units, probably related to Taconian accretionary events along the Laurentian margin.

Acknowledgements. E. W. Stokke assisted in the field and lab, G. Fjeld Bye (UiO) prepared samples, and thin-sections have been made by S. Akhavan (UiO). Geochemical analyses have been performed by J. Schönenberger, A. E. Karlsen, $\varnothing$. Skår and T. S. Røhr at NGU. Discussions with Magnus Kristoffersen and Tom Andersen are highly appreciated. This paper is part of the Ph.D. work of B. H. Dalsläen which is funded by the University of Oslo; fieldwork and analyses are partly funded by the Geological Survey of Norway project number 353000. Constructive comments by an anonymous reviewer and editor Trond Slagstad are highly appreciated. 


\section{References}

Andersen, T.B. 1981: The structure of the Magerøy Nappe, Finnmark, North Norway. Norges geologiske unders $\varnothing$ kelse $363,1-23$.

Andersen, T. 2013: Age, $\mathrm{Hf}$ isotope and trace element signatures of detrital zircons in the Mesoproterozoic Eriksfjord sandstone, southern Greenland: are detrital zircons reliable guides to sedimentary provenance and timing of deposition? Geological Magazine 150, 426-440.

https://doi.org/10.1017/S0016756812000623.

Andersen, T., Andersson, U.B., Graham, S., Åberg, G. \& Simonsen, S.L. 2009: Granitic magmatism by melting of juvenile continental crust: new constraints on the source of Palaeoproterozoic granitoids in Fennoscandia from Hf isotopes in zircon. Journal of the Geological Society 166, 233-247. https://doi.org/10.1144/0016-76492007-166.

Andersen, T., Kristoffersen, M. \& Elburg, M.A. 2018: Visualizing, interpreting and comparing detrital zircon age and $\mathrm{Hf}$ isotope data in basin analysis-a graphical approach. Basin Research 30, 132-147. https://doi.org/10.1111/bre.12245.

Andersen, T., Elburg, M.A. \& Magwaza, B.N. 2019: Sources of bias in detrital zircon geochronology: Discordance, concealed lead loss and common lead correction. Earth-Science Reviews 197, 102899. https://doi.org/10.1016/j.earscirev.2019.102899.

Augland, L.E., Andresen, A., Corfu, F., Simonsen, S.L. \& Andersen, T. 2012: The Beiarn nappe complex: a record of Laurentian Early Silurian arc magmatism in the Uppermost Allochthon, Scandinavian Caledonides. Lithos 146, 233-252. https://doi.org/10.1016/j.lithos.2012.05.016.

Barnes, C.G., Frost, C.D., Yoshinobu, A.S., McArthur, K., Barnes, M.A., Allen, C.M., Nordgulen, $\varnothing$. \& Prestvik, T. 2007: Timing of sedimentation, metamorphism, and plutonism in the Helgeland Nappe Complex, north-central Norwegian Caledonides. Geosphere 3, 683-703. https://doi.org/10.1130/GES00138.1.

Barnes, C.G., Reid, K., Frost, C.D., Barnes, M.A., Allen, C.M. \& Yoshinobu, A.S. 2011: Ordovician and Silurian magmatism in the Upper Nappe, Uppermost Allochthon, Helgeland Nappe Complex, north-central Norway. Norwegian Journal of Geology 91, 121-136.

Bjørlykke, A. \& Olaussen, S. 1981: Silurian sediments, volcanics and mineral deposits in the Sagelvvatn area, Troms, North Norway. Norges geologiske undersøkelse 365, 1-38.

Boyle, A. 1989: The geochemistry of the Sulitjelma ophiolite and associated basic volcanics: tectonic impilcations. In Gayer, R.A. (ed.): The Caledonide Geology of Scandinavia. Graham \& Trotman, pp. 153-163. https://doi.org/10.1007/978-94-009-2549-6_13.

Cas, R. \& Wright, J.V. 1988: Volcanic successions modern and ancient: A geological approach to processes, products and successions. Springer Science \& Business Media, 528 pp.

https://doi.org/10.1007/978-94-009-3167-1. 
Corfu, F., Torsvik, T., Andersen, T., Ashwal, L., Ramsay, D. \& Roberts, R. 2006: Early Silurian maficultramafic and granitic plutonism in contemporaneous flysch, Magerøy, northern Norway: $\mathrm{U}-\mathrm{Pb}$ ages and regional significance. Journal of the Geological Society 163, 291-301.

https://doi.org/10.1144/0016-764905-014.

Corfu, F., Andersen, T. \& Gasser, D. 2014: The Scandinavian Caledonides: main features, conceptual advances and critical questions. Geological Society, London, Special Publications 390, 9-43.

https://doi.org/10.1144/SP390.25.

Coutts, D.S., Matthews, W.A. \& Hubbard, S.M. 2019: Assessment of widely used methods to derive depositional ages from detrital zircon populations. Geoscience Frontiers 10, 1421-1435.

https://doi.org/10.1016/j.gsf.2018.11.002.

Dalslåen, B., Gasser, D., Grenne, T., Augland, L. \& Corfu, F. 2020a: Ordovician shoshonitic to ultrapotassic volcanism in the central Norwegian Caledonides: The result of sediment subduction, mantle metasomatism and mantle partial melting. Lithos 356, 105372.

https://doi.org/10.1016/j.lithos.2020.105372.

Dalslåen, B.H., Gasser, D., Grenne, T., Augland, L.E. \& Andresen, A. 2020b: Early to Middle Ordovician sedimentation and bimodal volcanism at the margin of lapetus: The Trollhøtta-Kinna basin of the Central Norwegian Caledonides. In Murphy, J., Strachan, R. \& Quesada, C. (eds.): Pannotia To Pangaea: Neoproterozoic and Paleozoic Orogenic Cycles in the Circum-Atlantic Region 503, Geological Society, London, Special Publications, London, pp. 251-277. https://doi.org/10.1144/SP503-2020-37.

Dickinson, W.R. \& Gehrels, G.E. 2009: Use of U-Pb ages of detrital zircons to infer maximum depositional ages of strata: a test against a Colorado Plateau Mesozoic database. Earth and Planetary Science Letters 288, 115-125. https://doi.org/10.1016/j.epsl.2009.09.013.

Domeier, M. 2016: A plate tectonic scenario for the lapetus and Rheic oceans. Gondwana Research 36, 275-295. https://doi.org/10.1016/j.gr.2015.08.003.

Dunning, G. \& Pedersen, R. 1988: U/Pb ages of ophiolites and arc-related plutons of the Norwegian Caledonides: implications for the development of lapetus. Contributions to Mineralogy and Petrology 98, 13-23. https://doi.org/10.1007/BF00371904.

Furnes, H. \& Lippard, S.J. 1983: Devonian lavas from Solund, West Norway - field relationships and geochemistry. Norges Geologiske Unders økelse Skrifter 328, 1-15.

Furnes, H., Dilek, Y. \& Pedersen, R.B. 2012: Structure, geochemistry, and tectonic evolution of trench-distal backarc oceanic crust in the western Norwegian Caledonides, Solund-Stavfjord ophiolite (Norway). Geological Society of America Bulletin 124, 1027-1047. https://doi.org/10.1130/B30561.1.

Gale, A., Dalton, C.A., Langmuir, C.H., Su, Y. \& Schilling, J.G. 2013: The mean composition of ocean ridge basalts. Geochemistry, Geophysics, Geosystems 14, 489-518. https://doi.org/10.1029/2012GC004334.

Gautneb, H. \& Roberts, D. 1989: Geology and petrochemistry of the Smøla-Hitra Batholith, central Norway. Norges geologiske undersøkelse Bulletin 416, 1-24.

Gee, D., Guezou, J., Roberts, D. \& Wolff, F. 1985: The central-southern part of the Scandinavian Caledonides. The Caledonide orogen-Scandinavia and related areas 1, 109-133. 
Gee, D.G., Fossen, H., Henriksen, N. \& Higgins, A.K. 2008: From the early Paleozoic platforms of Baltica and Laurentia to the Caledonide Orogen of Scandinavia and Greenland. Episodes 31, 44-51. https://doi.org/10.18814/epiiugs/2008/v31i1/007.

Goldschmidt, V.M. 1916: Geologisch-Petrographische Studien im Hochgebirge des Südlischen Norwegens. IV Überschit der Eruptivgesteine im Kaledonishen Gebirge Zwischen Stavanger und Trondhjem. Skrifter Videnskapelig-Selskap Christiania I. Mat-naturv. KI.no. 2 2, 140.

Grenne, T. \& Roberts, D. 1998: The Hølonda Porphyrites, Norwegian Caledonides: geochemistry and tectonic setting of Early-Mid-Ordovician shoshonitic volcanism. Journal of the Geological Society 155, 131-142. https://doi.org/10.1144/gsjgs.155.1.0131.

Hartz, E.H., Martin, M.W., Andresen, A. \& Andersen, T.B. 2002: Volcanic rocks in the Devonian Solund Basin, Western Norway: large landslides of Silurian (439 Ma) rhyolites. Journal of the Geological Society 159, 121-128. https://doi.org/10.1144/0016-764901-063.

Hermann, J. \& Rubatto, D. 2009: Accessory phase control on the trace element signature of sediment melts in subduction zones. Chemical Geology 265, 512-526.

https://doi.org/10.1016/j.chemgeo.2009.05.018.

Hollocher, K., Robinson, P., Seaman, K. \& Walsh, E. 2016: Ordovician-early Silurian intrusive rocks in the northwest part of the Upper Allochthon, mid-Norway: Plutons of an lapetan volcanic arc complex. American Journal of Science 316, 925-980. https://doi.org/10.2475/10.2016.01

Holmsen, P. 1955: Trekk av Opdalsfeltets geologi. Norsk Geologisk Tidsskrift 35, 135-150.

Ingdahl, S. 1989: The Upper Ordovician-Lower Silurian rocks in the Os area, Major Bergen Arc, Western Norway. Norsk Geologisk Tidsskrift 69, 163-175.

Krill, A.G. 1980: Tectonics of the Oppdal area, central Norway. Geologiska Föreningen i Stockholm Förhandlingar 102, 523-530. https://doi.org/10.1080/11035898009454505.

Krill, A.G. 1985: Relationships between the Western Gneiss Region and the Trondheim Region : Stockwerk-tectonics reconsiderd. In Gee, D. \& Sturt, B. (eds.): The Caledonide Orogen - Scandinavia and Related Areas, John Wiley \& Sons Ltd, pp. 475-483.

Lee, J.-Y., Marti, K., Severinghaus, J.P., Kawamura, K., Yoo, H.-S., Lee, J.B. \& Kim, J.S. 2006: A redetermination of the isotopic abundances of atmospheric Ar. Geochimica et Cosmochimica Acta 70 , 4507-4512. https://doi.org/10.1016/j.gca.2006.06.1563.

Lindahl, I., Stevens, B.P. \& Zwaan, K.B. 2005: The geology of the Vaddas area, Troms: a key to our understanding of the Upper Allochthon in the Caledonides of northern Norway. Norges Geologiske undersøkelse Bulletin 445, 5-43.

Meyer, G., Grenne, T. \& Pedersen, R. 2003: Age and tectonic setting of the Nesåa Batholith: implications for Ordovician arc development in the Caledonides of Central Norway. Geological Magazine 140, 573-594. https://doi.org/10.1017/\$0016756803008069.

Neuman, R. \& Bruton, D. 1989: Brachiopods and trilobites from the Ordovician Lower Hovin Group (Arenig/Llanvirn), Hølonda area, Trondheim region, Norway: new and revised taxa and paleogeographic interpretation. Norges geologiske undersøkelse Bulletin 414, 49-89. 
Neuman, R.B., Pojeta Jr, J. \& Bruton, D.L. 1997: Fossils from the Ordovician" Upper Hovin Group" (Caradoc-Ashgill), Trondheim Region, Norway. Norges geologiske undersøkelse Bulletin 432, 25-58.

Nilsen, O. \& Wolff, F.C. 1989: Røros og Sveg. Berggrunnskart Røros og Sveg, scale 1:250000, Norges Geologiske Undersøkelse.

Nilsen, O., Sundvoll, B., Roberts, D. \& Corfu, F. 2003: U-Pb geochronology and geochemistry of trondhjemites and a norite pluton from the SW Trondheim Region, Central Norwegian Caledonides. Norges Geologiske Undersøkelse Bulletin 441, 5-16.

Nilsen, O., Corfu, F. \& Roberts 2007: Silurian gabbro-diorite-trondhjemite plutons in the Trondheim Nappe Complex, Caledonides, Norway; petrology and U-Pb geochronology. Norwegian Journal of Geology 87, 329-342.

Nordås, J., Amaliksen, K., Brekke, H., Suthern, R., Furnes, H., Sturt, B., Robins, B. \& Gee, D. 1985: Lithostratigraphy and petrochemistry of Caledonian rocks on Bømlo, SW Norway. In Gee, D.G. \& Sturt, B.A. (eds.): The Caledonide Orogen-Scandinavia and Related Areas, John Wiley \& Sons Ltd, New York, pp. 679-692.

Pearce, J.A. 1996: A user's guide to basalt discrimination diagrams. In Wyman, D.A. (ed.): Trace element geochemistry of volcanic rocks: applications for massive sulphide exploration, Geological Association of Canada, Short Course Notes 12, pp. 79-113.

Pearce, J.A. 2008: Geochemical fingerprinting of oceanic basalts with applications to ophiolite classification and the search for Archean oceanic crust. Lithos 100, 14-48. https://doi.org/10.1016/j.lithos.2007.06.016.

Pearce, J.A. \& Peate, D.W. 1995: Tectonic implications of the composition of volcanic arc magmas. Annual review of Earth and planetary sciences 23, 251-285.

https://doi.org/10.1146/annurev.ea.23.050195.001343.

Pedersen, R.B. \& Dunning, G.R. 1997: Evolution of arc crust and relations between contrasting sources: $\mathrm{U}-\mathrm{Pb}$ (age), $\mathrm{Nd}$ and $\mathrm{Sr}$ isotope systematics of the ophiolitic terrain of SW Norway. Contributions to Mineralogy and Petrology 128, 1-15. https://doi.org/10.1007/s004100050289.

Pedersen, R., Furnes, H. \& Dunning, G. 1991: A U/Pb age for the Sulitjelma Gabbro, North Norway: further evidence for the development of a Caledonian marginal basin in Ashgill-Llandovery time. Geologic Magazine 128, 141-153. https://doi.org/10.1017/\$0016756800018331.

Pedersen, R., Bruton, D. \& Furnes, H. 1992: Ordovician faunas, island arcs and ophiolites in the Scan-dinavian Caledonides. Terra Nova 4, 217-222.

https://doi.org/10.1111/j.1365-3121.1992.tb00475.x.

Renne, P.R., Mundil, R., Balco, G., Min, K. \& Ludwig, K.R. 2010: Joint determination of 40K decay constants and 40Ar*/40K for the Fish Canyon sanidine standard, and improved accuracy for $40 \mathrm{Ar} / 39 \mathrm{Ar}$ geochronology. Geochimica et Cosmochimica Acta 74, 5349-5367.

https://doi.org/10.1016/j.gca.2010.06.017.

Roberts, D., Melezhik, V. \& Heldal, T. 2002: Carbonate formations and early NW-diected thrusting in the highest allochthons of the Norwegian Caledonides. Journal of the Geological Society of London 159, 117-120. https://doi.org/10.1144/0016-764901-128. 
Roberts, D., Nordgulen, O. \& Melezhik, V. 2007: The Uppermost Allochthon in the Scandinavian Caledonides: From a Laurentian ancestry through Taconian orogeny to Scandian crustal growth on Baltica. In Hatcher Jr., R.D., Carlson, M.P., McBride, J.H. \& Martinez Catalan, J.R. (eds.): 4-D Framework of Continental Crust, Geological Society of America Memoir 200, pp. 357-377. https://doi.org/10.1130/2007.1200(18).

Roberts, D., Morton, A. \& Frei, D. 2019: A Silurian age for the metasedimentary rocks of the Ekne Group, Trøndelag, Mid-Norwegian Caledonides: and inferences for a peri-Laurentian provenance. Norwegian Journal of Geology 99, 583-595. https://doi.org/10.17850/njg99-4-3.

Rohr-Torp, E. 1972: A major inversion of the western part of the Trondheim nappe. Norwegian Journal of Geology 52, 453-458.

Rohr-Torp, E. 1974: Contact metamorphism around the Innset massif. Norwegian Journal of Geology $54,13-33$.

Rowland, S.K. \& Walker, G.P. 1990: Pahoehoe and aa in Hawaii: volumetric flow rate controls the lava structure. Bulletin of Volcanology 52, 615-628. https://doi.org/10.1007/BF00301212.

Ryan, P.D., Williams, D. \& Skevington, D. 1980: Revised interpretation of the Ordovician stratigraphy of Sør Trøndelag, and its implications for the evolution of the Scandinavian Calcdonides. In Wones, D. \& Blackburn, W. (eds.): The Caledonides in the USA" : I.G.C.P.project 27: Caledonide orogen, Virginia Polytechnic Institute, pp. 99-104.

Slagstad, T. \& Kirkland, C.L. 2018: Timing of collision initiation and location of the Scandian orogenic suture in the Scandinavian Caledonides. Terra Nova 30, 179-188. https://doi.org/10.1111/ter.12324.

Slagstad, T., Pin, C., Roberts, D., Kirkland, C.L., Grenne, T., Dunning, G., Sauer, S. \& Andersen, T. 2014: Tectonomagmatic evolution of the Early Ordovician suprasubduction-zone ophiolites of the Trondheim Region, Mid-Norwegian Caledonides. Geological Society, London, Special Publications 390, 541-561. https://doi.org/10.1144/SP390.11.

Stokke, E.W., Gasser, D., Dalslåen, B.H. \& Grenne, T. 2018: Tectonic evolution of syn-to late-orogenic sedimentary-volcanic basins in the central Norwegian Caledonides. Journal of the Geological Society 175, 605-618. https://doi.org/10.1144/jgs2017-091.

Sun, S.-S. \& McDonough, W.-S. 1989: Chemical and isotopic systematics of oceanic basalts: implications for mantle composition and processes. Geological Society, London, Special Publications 42, 313-345. https://doi.org/10.1144/GSL.SP.1989.042.01.19.

Tucker, R.D., Robinson, P., Solli, A., Gee, D.G., Thorsnes, T., Krogh, T.E., Nordgulen, $\varnothing$. \& Bickford, M. 2004: Thrusting and extension in the Scandian hinterland, Norway: New U-Pb ages and tectonostratigraphic evidence. American Journal of Science 304, 477-532.

https://doi.org/10.2475/ajs.304.6.477.

van Staal, C.R., Whalen, J.B., Valverde-Vaquero, P., Zagorevski, A. \& Rogers, N. 2009: Pre-Carboniferous, episodic accretion-related, orogenesis along the Laurentian margin of the northern Appalachians. Geological Society, London, Special Publications 327, 271-316. https://doi.org/10.1144/SP327.13. 
Vissers, R.L., Ganerød, M., Pennock, G.M. \& van Hinsbergen, D.J. 2020: Eocene seismogenic reactivation of a Jurassic ductile shear zone at Cap de Creus, Pyrenees, NE Spain. Journal of Structural Geology 134, 103994. https://doi.org/10.1016/j.jsg.2020.103994.

Vogt, T. 1945: The geology of part of the Hølonda-Horg district, a type area in the Trondheim region. Norwegian Journal of Geology 25, 449-528.

Wilson, J.T. 1966: Did the Atlantic close and then re-open? Nature 211, 676-681.

https://doi.org/10.1038/211676a0.

Yoshinobu, A.S., Barnes, C.G., Nordgulen, Ø., Prestvik, T., Fanning, M. \& Pedersen, R. 2002: Ordovician magmatism, deformation, and exhumation in the Caledonides of central Norway: An orphan of the Taconic orogeny? Geology 30, 883-886.

https://doi.org/10.1130/0091-7613(2002)030<0883:OMDAEl>2.0.CO;2. 